\title{
ॠUSGS
}

science for a changing world

Prepared in Cooperation with the U.S. Fish and Wildlife Service

\section{Monitoring of Wild Fish Health at Selected Sites in the Great Lakes Basin: Methods and Preliminary Results}
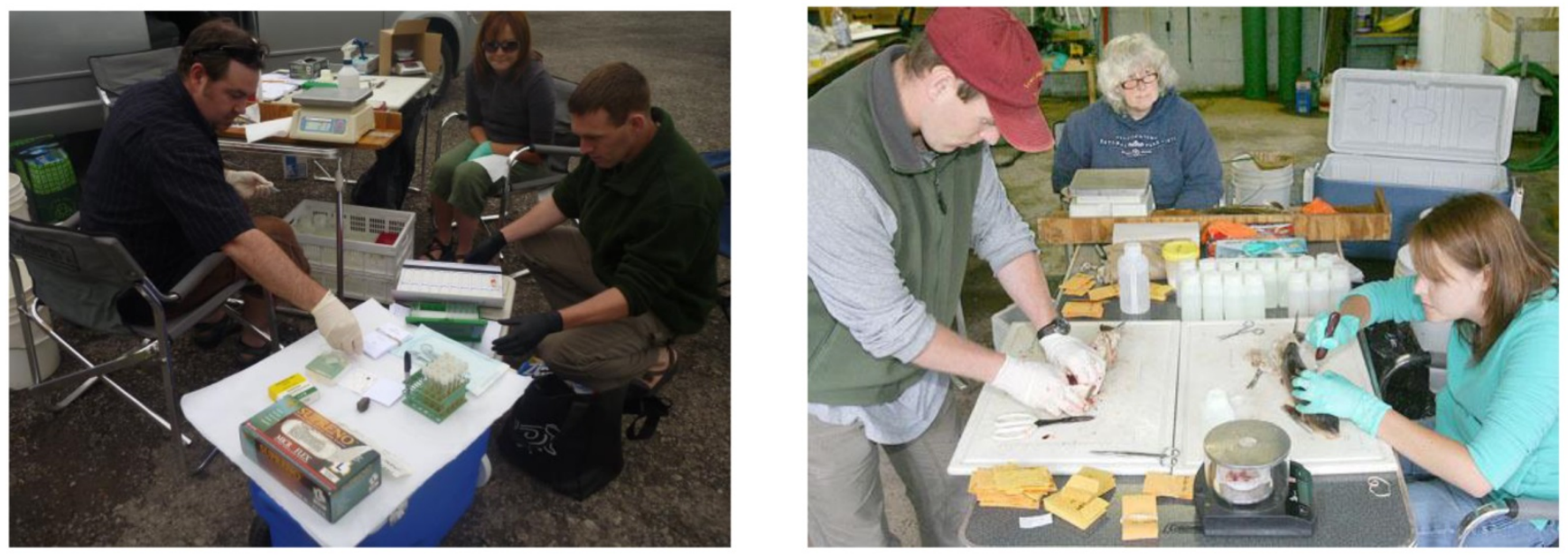

Open-File Report 2014-1027

U.S. Department of the Interior

U.S. Geological Survey 
Cover: Left photograph Dr. Luke Iwanowicz and graduate students Cassidy Hahn and Ryan Braham sampling fish. Right photograph Dr. Vicki Blazer and graduate students Cassidy Hahn and Ryan Braham sampling fish. 


\section{Monitoring of Wild Fish Health at Selected Sites in the Great Lakes Basin: Methods and Preliminary Results}

By Vicki S. Blazer, Patricia M. Mazik, Luke R. Iwanowicz, Ryan Braham, Cassidy Hahn, Heather L. Walsh, and Adam Sperry

Prepared in Cooperation with the U.S. Fish and Wildlife Service

Open-File Report 2014-1027

U.S. Department of the Interior

U.S. Geological Survey 


\section{U.S. Department of the Interior \\ SALLY JEWELL, Secretary}

\section{U.S. Geological Survey \\ Suzette M. Kimball, Acting Director}

U.S. Geological Survey, Reston, Virginia: 2014

For more information on the USGS—-the Federal source for science about the Earth, its natural and living resources, natural hazards, and the environment-visit http://www.usgs.gov or call 1-888-ASK-USGS (1-888-275-8747)

For an overview of USGS information products, including maps, imagery, and publications, visit $h t t p: / / w w w . u s g s . g o v / p u b p r o d$

To order this and other USGS information products, visit http://store.usgs.gov

Any use of trade, firm, or product names is for descriptive purposes only and does not imply endorsement by the U.S. Government.

Although this information product, for the most part, is in the public domain, it also may contain copyrighted materials as noted in the text. Permission to reproduce copyrighted items must be secured from the copyright owner.

This draft manuscript is distributed solely for purposes of scientific peer review. Its content is deliberative and predecisional, so it must not be disclosed or released by reviewers. Because the manuscript has not yet been approved for publication by the U.S. Geological Survey, it does not represent any official USGS finding or policy.

Suggested citation:

Blazer, V.S., Mazik, P.M., Iwanowicz, L.R., Braham, Ryan, Hahn, Cassidy, Walsh, H.L., and Sperry, Adam, 2014, Monitoring of Wild Fish Health at Selected Sites in the Great Lakes Basin-Methods and Preliminary Results: U.S. Geological Survey Open-File Report 2014-1027 p. 31, http://dx.doi.org/10.3133/ofr20141027. 


\section{Acknowledgments}

This project was funded by the Great Lakes Restoration Initiative through a grant to Region 3 Fish and Wildlife Service Contaminants program and by the U.S. Geological Survey's Environments (Fisheries) and Cooperative Fish and Wildlife Research Unit programs. The authors thank the U.S. Fish and Wildlife Service personnel for field logistic arrangements and fish collections, especially Jo Ann Banda, Steven Choy, Daniel Gefell, Zachary Jorgensen, Jeremy Moore and Sara Warner. We thank U.S. Geological Survey histology technicians Darlene Bowing and Kathy Spring for their assistance. 


\section{Contents}

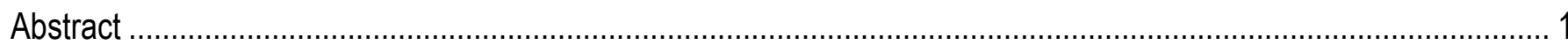

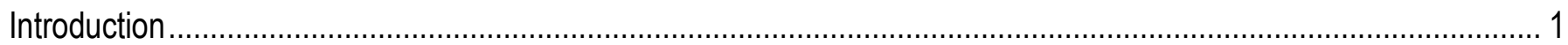

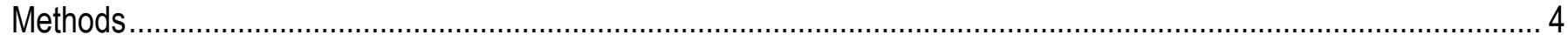

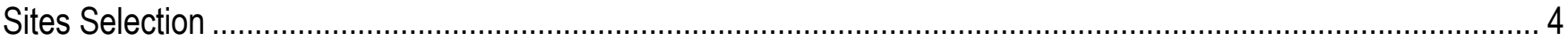

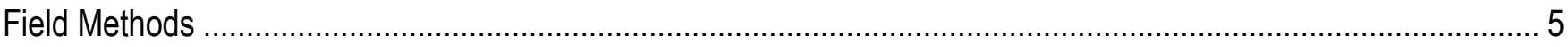

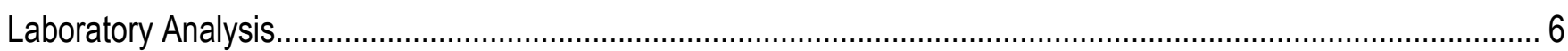

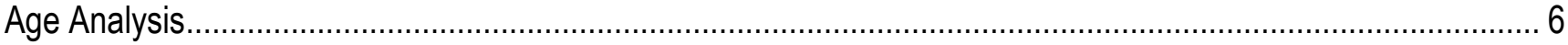

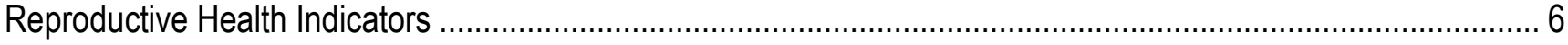

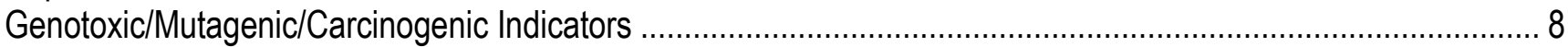

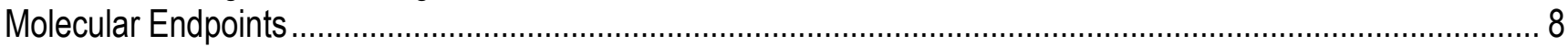

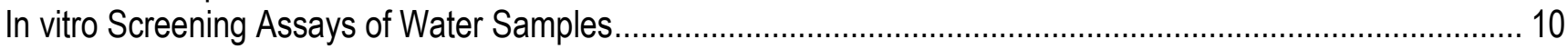

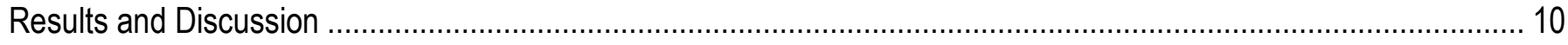

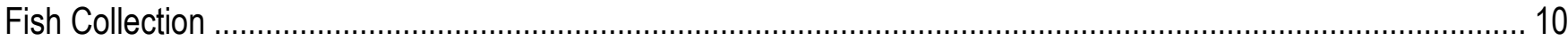

Morphometric, Condition Factor and hepotosomatic Index ........................................................................ 12

Smallmouth and Largemouth Bass ...................................................................................................... 12

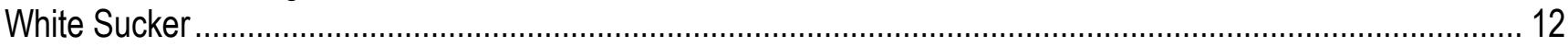

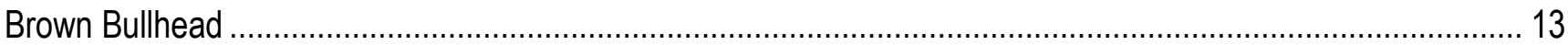

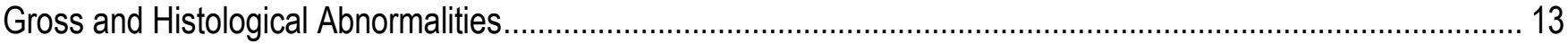

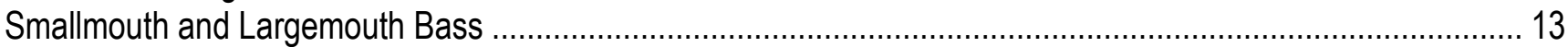

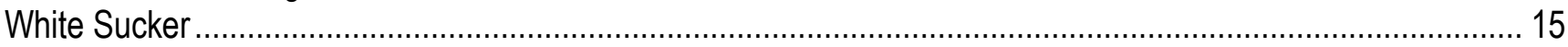

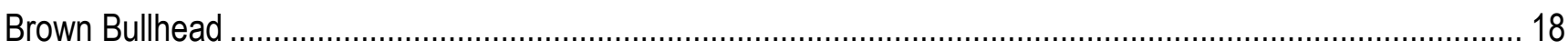

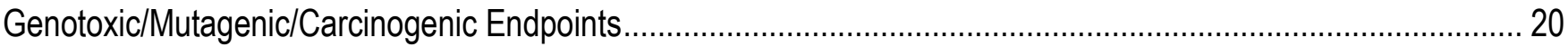

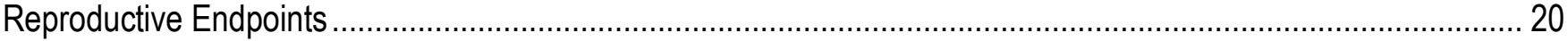

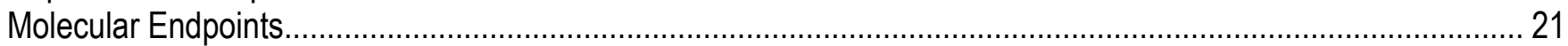

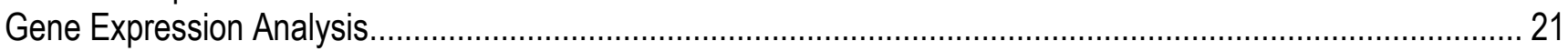

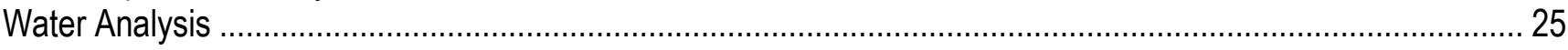

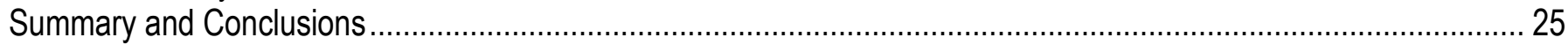

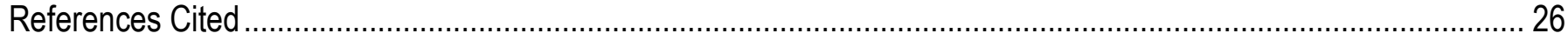

\section{Figures}

1. Sampling sites for fish collections conducted in the Great Lakes Basin during 2010-2011..........................5

2. Grossly visible lesions observed on smallmouth and largemouth bass ................................................ 14

3. Microscopic pathology of skin lesions observed on bass................................................................... 15

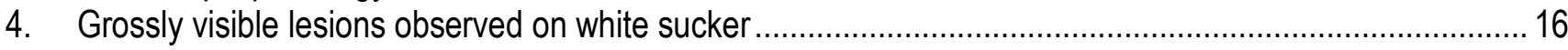

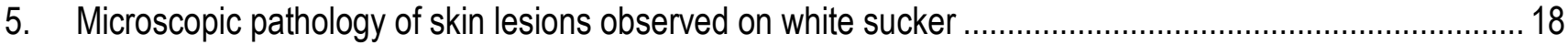

6. Grossly visible lesions observed on brown bullhead...................................................................... 19

\section{Tables}

1. Sampling site Areas of Concern and locations in the Great Lakes Basin .............................................. 10

2. Summary of Fishes Collected for Fish Health Assessments in selected Areas of Concern in the

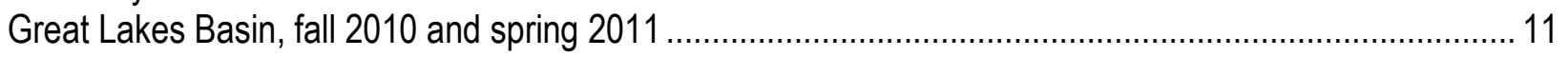

3. Morphometric parameters of largemouth and smallmouth bass collected in the Great Lakes Basin, 2010-20111 
4. Morphometric parameters of white sucker collected in the Great Lakes Basin, 2010-2011 ....................... 13

5. Morphometric parameters of brown bullhead collected in the Great Lakes Basin, 2010-2011 ................... 13

6. Percentage of largemouth and smallmouth bass with visible eye or skin lesions, Great Lakes Basin,

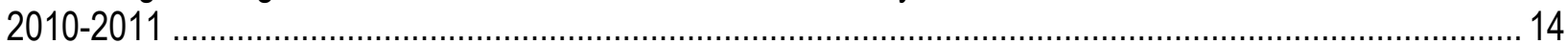

7. Percentage of white sucker with visible eye or skin lesions, Great Lakes Basin, 2010-2011 .....................17

8. Percentage of brown bullhead with visible eye, barbel or skin lesions, Great Lakes Basin, 2010-2011 ......20

9. Genes chosen for NanoString analysis of individual liver samples ........................................................ 21

10. Regulation in the top 25 target genes between female and male smallmouth bass collected in the

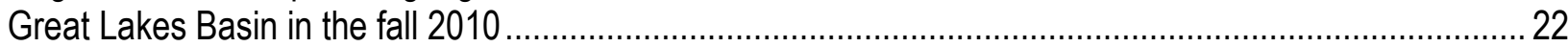

11. Regulation in the top 25 target genes between female and male smallmouth bass collected in the Great Lakes Basin in spring 2011

12. Regulation of the top 25 target genes between seasons, fall 2010 and spring 2011, in female smallmouth bass collected in the Great Lakes Basin. 


\section{Conversion Factors}

\begin{tabular}{lcll} 
Inch/Pound to SI & Multiply & & To obtain \\
\hline & By & & \\
\hline inch (in.) & 2.54 & centimeter (cm) & \\
inch (in.) & 25.4 & millimeter (mm) & \\
foot (ft) & 0.3048 & meter (m) \\
mile (mi) & 1.609 & kilometer (km) \\
yard (yd) & 0.9144 & meter (m) \\
\hline & Volume & \\
\hline ounce, fluid (fl. oz) & 0.02957 & liter (L) \\
pint (pt) & 0.4732 & liter (L) \\
quart (qt) & 0.9464 & liter (L) \\
gallon (gal) & 3.785 & liter (L) \\
\hline & Mass & \\
\hline ounce, avoirdupois (oz) & 28.35 & gram (g) \\
pound, avoirdupois (lb) & 0.4536 & kilogram (kg) \\
\hline
\end{tabular}

SI to Inch/Pound

\begin{tabular}{|c|c|c|}
\hline Multiply & By & To obtain \\
\hline \multicolumn{3}{|c|}{ Length } \\
\hline centimeter $(\mathrm{cm})$ & 0.3937 & inch (in.) \\
\hline millimeter (mm) & 0.03937 & inch (in.) \\
\hline $\operatorname{meter}(\mathrm{m})$ & 3.281 & foot $(\mathrm{ft})$ \\
\hline kilometer (km) & 0.6214 & mile (mi) \\
\hline $\operatorname{meter}(\mathrm{m})$ & 1.094 & yard (yd) \\
\hline \multicolumn{3}{|c|}{ Volume } \\
\hline liter (L) & 33.82 & ounce, fluid (fl. oz) \\
\hline liter (L) & 2.113 & $\operatorname{pint}(\mathrm{pt})$ \\
\hline liter (L) & 1.057 & quart (qt) \\
\hline liter $(\mathrm{L})$ & 0.2642 & gallon (gal) \\
\hline \multicolumn{3}{|c|}{ Mass } \\
\hline $\operatorname{gram}(\mathrm{g})$ & 0.03527 & ounce, avoirdupois (oz) \\
\hline kilogram (kg) & 2.205 & pound avoirdupois (lb) \\
\hline
\end{tabular}




\title{
Monitoring of Wild Fish Health at Selected Sites in the Great Lakes Basin: Methods and Preliminary Results
}

\author{
By Vicki S. Blazer ${ }^{1}$, Patricia M. Mazik¹, Luke R. Iwanowicz¹, Ryan Braham², Cassidy Hahn², Heather L. Walsh², \\ and Adam Sperry²
}

\begin{abstract}
During fall 2010 and spring 2011, a total of 119 brown bullhead (Ameiurus nebulosus), 136 white sucker (Catostomus commersoni), 73 smallmouth bass (Micropterus dolomieu), and 59 largemouth bass (M. salmoides) were collected from seven Great Lakes Basin Areas of Concern and one Reference Site. Comprehensive fish health assessments were conducted in order to document potential adverse effects from exposure to complex chemical mixtures. Fish were necropsied on site, blood samples obtained, pieces of liver, spleen, kidney, gill and any abnormalities placed in fixative for histopathology. Liver samples were saved for gene expression analysis and otoliths were removed for aging. A suite of fish health indicators was developed and implemented for site comparisons and to document seasonal effects and species differences in response to environmental conditions. Organism level (grossly visible lesions, condition factor), tissue level (microscopic pathology, organosomatic indices, micronuclei, and other nuclear abnormalities), plasma factors (reproductive steroid hormones, vitellogenin), and molecular (gene expression) indicators were included. This report describes the methods and preliminary results.
\end{abstract}

\section{Introduction}

The Great Lakes Restoration Initiative (GLRI) began in 2010, specifically targeting certain priorities, including cleaning up toxic substances, restoring wetlands and other habitats, promoting nearshore health by protecting watersheds from contaminants in run-off, and evaluating and monitoring progress at Areas of Concern (AOCs). AOCs are defined by the United States-Canada Great Lakes Water Quality Agreement, Annex 2 of the 1987 Protocol as "geographic areas that fail to meet the general or specific objectives of the agreement where such failure has caused or is likely to cause impairment of beneficial use of the area's ability to support aquatic life." Fourteen beneficial use impairments (BUIs) were defined by the International Joint Commission (IJC). These include a number of impairments in fish and wildlife populations such as fish tumors or other deformities, degraded fish and wildlife populations, loss of fish and wildlife habitat, and restrictions on fish and wildlife consumption (IJC 1991). Initially, the focus of AOCs was on legacy contaminants such as metals, polyaromatic hydrocarbons and polycyclic aromatic biphenyls. Recent studies recognized that chemicals of emerging concern (CEC) may contribute to impaired fish and wildlife health in the Great Lakes (IJC, 2009, Klečka et al., 2010; Klaper and Welch, 2011). These CEC include organic substances

\footnotetext{
${ }^{1}$ U.S. Geological Survey.

${ }^{2}$ West Virginia University.
} 
such as biogenic hormones (human and animal), brominated flame retardants, pharmaceuticals, personal care products, plasticizers, current-use pesticides, and detergents, from human wastewater, agricultural and industrial sources.

There has been a substantive increase in the detection of CEC in the aquatic environment, including the Great Lakes watershed (Metcalfe et al., 2003; Li et al., 2010; Blair et al., 2013; Ferguson et al., 2013). These contaminants frequently were not regulated and are inadequately monitored by state or Federal water-quality programs. The IJC has recognized that while information exists regarding the presence of such chemicals in the Great Lakes watershed, few data were available regarding effects of exposure. Failure to identify and understand the effects of the complex mixtures of chemical contaminants and other environmental stressors on fish and wildlife resources may result in deleterious effects on Great Lakes resources with adverse ecological, economic, and recreational consequences. Identifying adverse effects on fish health and potential sources of contaminants is necessary for addressing management strategies directed toward healthier fish populations.

With GLRI funding, the U.S. Fish and Wildlife Service (FWS) Environmental Contaminants Programs initiated an early warning program to detect and identify CECs in the Great Lakes Basin and their effects on fish and wildlife. This program was part of a multiagency monitoring and surveillance effort (Ekman et al. 2013) that includes chemical sampling of water and sediment (Lee et al. 2012) and caged fish studies at selected sites in addition to identification of potential adverse effects on resident wild fishes. The U.S. Geological Survey (USGS) and West Virginia Cooperative Fish and Wildlife Research Unit, West Virginia University, developed a suite of endpoints and implemented monitoring/surveillance for detection of adverse biological effects in wild fishes.

The suite of indicators includes biomarkers from the organism to the molecular level. Organismlevel indicators, such as necropsy-based and morphometric observations have been used in numerous monitoring programs and, although not as sensitive as histopathological or some other endpoints, provide important information at the organism level (Goede and Barton 1990; Schmitt and Dethloff 2000; Fournie et al. 1996). Tissue or organ-level indicators include endpoints such as hepatosomatic (HSI) and gonadosomatic (GSI) indices and the microscopic pathology (histopathology) of various tissues. Exposure to contaminants, including estrogenic compounds (Jobling et al., 1996; Jobling et al., 1998; Hassanin et al., 2002; Sindhe and Kulkarni, 2004) have been shown to influence gonadal growth and GSI. Numerous histopathological changes in tissues have been used as biomarkers of exposure and (or) environmental stress, including neoplasms and preneoplastic changes of liver and skin (Myers and Fournie, 2002; Stentiford et al., 2003; Au, 2004; Lyons et al., 2004). Histopathology of the gonads was used to verify sex and stage of gonadal development, as well as identify abnormalities such as testicular oocytes (Blazer, 2002; Dietrich and Krieger, 2009). Although effects on the reproductive system have been the most commonly documented, other systems can be affected by exposure to CECs and legacy contaminants. These include the thyroid and adrenal or interrenal/chromaffin tissue, as well as the immune system which can be examined microscopically.

Subcellular (plasma analyses) and molecular (gene expression) biomarkers are often reflective of more recent or acute exposure than the organism or tissue-level biomarkers. Vitellogenin, an egg-yolk precursor protein produced in response to estrogen and estrogen agonists, is normally found only in the serum of adult female oviparous vertebrates, but can be induced in males and immature females by estrogenic compounds or estrogen mimics. The presence of plasma vitellogenin in male fishes is a wellaccepted indicator of exposure to estrogenic endocrine disrupting chemicals (Tyler et al., 2007; Denslow et al., 1999; Cheek et al., 2001). In contrast, decreased levels of circulating vitellogenin in female fish may result in lowered egg quality (Wheeler et al., 2005; Miller et al., 2007). Hormones, including estradiol and 11-keto testosoterone, can be measured in plasma, and abnormal concentrations 
may be indicative of exposure to endocrine disruptors and other contaminants (Munkittrick et al., 1998; Sepúlveda et al., 2002; Hinck et al. 2007; Cheshenko et al. 2008).

Genotoxic pollutants may have mutagenic and (or) carcinogenic properties, that affect a cell's genetic material, causing mutations and in some cases contributing to the tumor development and neoplasia (Pinkney et al., 2011; Williams, 2012). A variety of methods have been used with fishes to detect exposure to genotoxic compounds. One of the easiest methods for use in field studies is assessment of red blood cell micronuclei and other nuclear abnormalities. Blood smears can be made immediately after blood collection, fixed, and then stained in the laboratory. This method has been widely used for assessing genotoxicity in many fish species (Al-Sabti and Metcalfe, 1995; Ayllón and Garcia-Vasquez, 2001; Rodriguez-Cea et al., 2003), including brown bullhead, Ameiurus nebulosus, and white sucker, Catostomus commersoni (Metcalfe, 1988; Smith, 1990). Although other methods have been used to assess genotoxicity or DNA damage in smallmouth bass, Micropterus dolomieu, (Chamberland et al., 2002) and largemouth bass Micropterus salmoides (Sugg et al., 1995; Lingenfelser et al., 1997), to our knowledge the micronuclei assay has not been previously evaluted in these species.

The species of choice were either brown bullhead or white sucker (benthic species) and either largemouth bass or smallmouth bass (pelagic species). Brown bullhead and white sucker have been used extensively in the Great Lakes Basin as watershed indicator species, particularly in relation to skin and liver tumors (Smith et al., 1989; Hayes et al., 1990; Premdas et al., 1995; Baumann et al., 1996; Blazer et al., 2009 a and b; Rafferty et al., 2009). White sucker have also demonstrated sensitivity to the effects of exposure to endocrine disruptors at sites within the Great Lakes Basin and elsewhere (Munkittrick and Dixon, 1989; Woodling et al., 2006; Bowron et al., 2009). Bass were a target species for the USGS Biomonitoring of Environmental Status and Trends (BEST) monitoring program (Schmitt, 2002; Hinck et al., 2007) and have been shown to be sensitive to endocrine-disrupting chemicals (Sepúlveda et al., 2002; Blazer et al., 2007b; Hinck et al., 2009; Iwanowicz et al., 2009; Blazer et al., 2012).

There were three major objectives of the research conducted by USGS from 2010 to 2011. The first objective was to evaluate the "fish tumor and other deformities" BUI at the St. Louis River AOC in Minnesota. This BUI was defined as occurring "when the incidence rates of fish tumors or other deformities exceed rates at unimpacted control sites or when survey data confirm the presence of neoplastic and preneoplastic liver tumors in bullheads or suckers" (International Joint Commission, 1991). The current status of this BUI was unknown for many AOCs, including the St. Louis River. The incidence of proliferative, possibly preneoplastic, and neoplastic skin and liver lesions was evaluated in terms of habitat usage in 200 white sucker captured within the river and estuary in spring 2011 (Blazer et al., 2014).

The second objective was to evaluate fish health at the Ashtabula River AOC in Ohio and Conneuat Creek in Ohio (reference site) in spring and fall 2011. The health of largemouth bass and brown bullhead was evaluated during 2002-04 prior to remediation and restoration (Blazer et al., 2006a; Iwanowicz et al., 2012). During 2010-11, the Ohio Environmental Protection Agency undertook habitat restoration projects to increase in-water and shoreline habitat and develop a fish shelf in the lower 2 miles of the river to provide habitat to forage and spawn. The objective of the 2011 sampling was to compare current fish health to pre-remediation findings. In the pre-remediation study, whole-body contaminant concentrations correlated to certain biomarkers, particularly immune system endpoints. More in-depth analyses are underway to demonstrate whether contaminant loads have decreased and the effect a decrease would have on biological endpoints (Iwanowicz et al., U.S. Geological Survey, written commun., 2014).

The third objective was to utilize a suite of endpoints in multiple species, spatially and seasonally, to identify potential adverse effects of emerging contaminants on fish health at sites within 
the Great Lakes Basin during 2010-2012. The purpose of this report is to present the methods used in the study and preliminary results of research conducted to address this third objective.

\section{Methods}

\section{Sites Selection}

Sites selected are AOCs suspected of being affected by CEC in municipal wastewater discharges or receiving waters of industrial facilities and (or) potential agricultural or urban nonpoint sources. Based on these characteristics, the following locations were selected for the fall 2010 sampling: Genesee River (Rochester Embayment AOC, New York), St. Louis River (St. Louis River and Bay AOC, Minnesota), Swan Creek (Maumee River AOC, Ohio), Detroit River (Detroit River AOC, Michigan) and Fox River (Lower Fox River/Green Bay AOC, Wisconsin). In spring 2011, the Milwaukee River (Milwaukee Estuary AOC, Wisconsin), Ashtabula River (Ashtabula River AOC, Ohio) and Conneaut Creek (Reference site, Ohio) were added to the list of sampling sites (Figure 1). Fish sampling sites are listed in Appendix 1. 


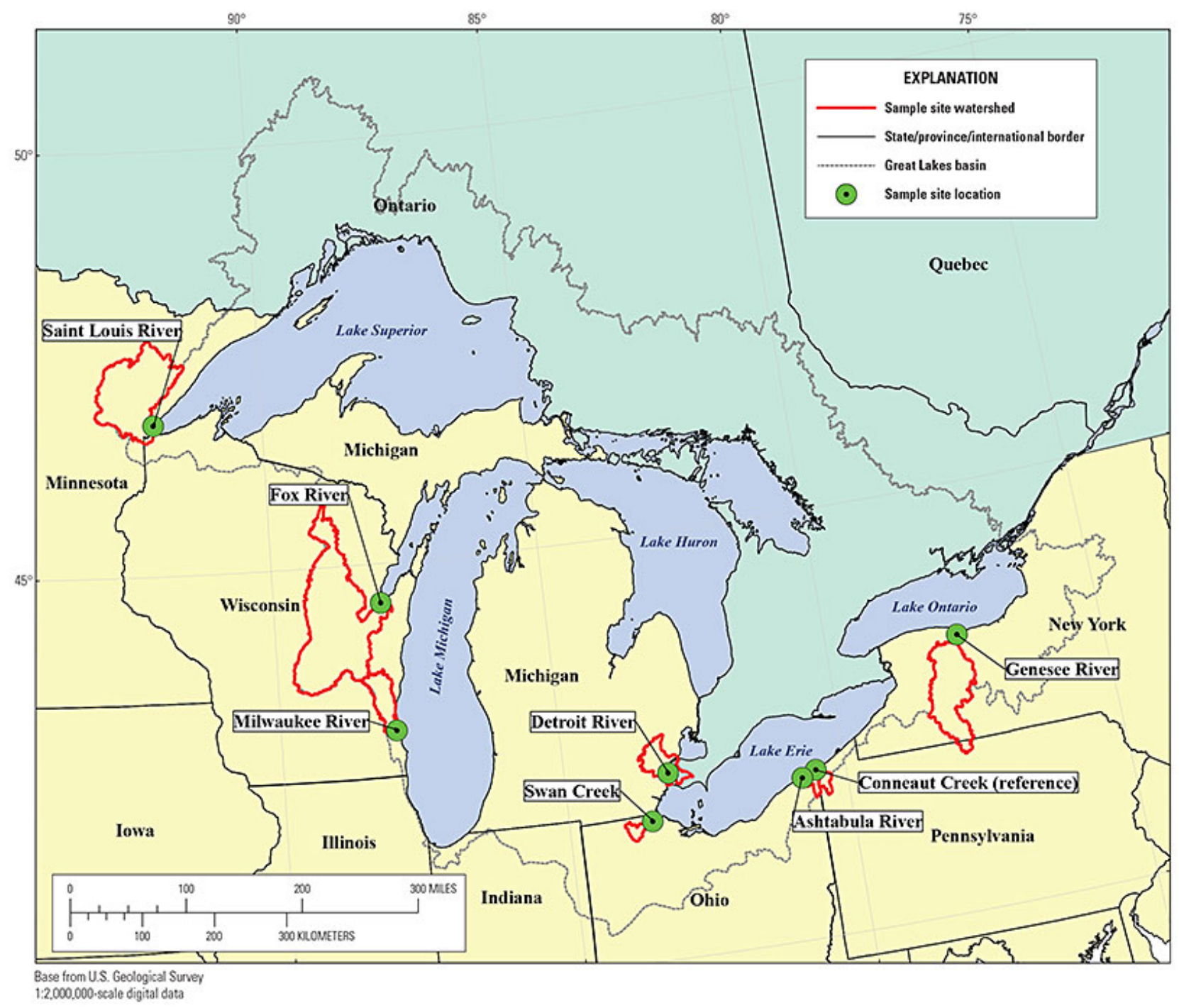

Figure 1. Sampling sites for fish collections conducted in the Great Lakes Basin during 2010-2011.

\section{Field Methods}

Attempts were made by FWS personnel to collect 20 mature fish (10 males and 10 females) from each of two species at each site by electrofishing, minnow traps, or fyke nets. Spring sampling in each year was intended to be conducted during the prespawn period. Fish were anesthetized with MS222 (Tricane Methanesulfonate, Argent Chemical Laboratories, Redmond, Washington), weighed to the nearest gram (gm) and measured (total length) to nearest millimeter (mm). Peripheral blood was extracted from the caudal vessels using a heparinized syringe. One drop of blood was placed onto each of two pre-cleaned glass slides and blood smears were prepared and allowed to dry. Slides were fixed with absolute methanol for 10 minutes. The remaining blood was stored on wet ice until centrifuged (same day) and plasma aliquoted into two cryovials. Plasma samples were stored in 1.5-mililiter $(\mathrm{mL})$ polypropylene microcentrifuge tubes (Fisher Scientific, Pittsburgh, Pennsylvania) at -80 degrees Celsius $\left({ }^{\circ} \mathrm{C}\right)$ until analyzed. A comprehensive necropsy-based assessment was completed on all fish 
collected (Goede and Barton, 1990; Smith et al., 2002; Rafferty and Grazio, 2006), and all visible abnormalities were documented. The liver and gonads were removed and weighed to calculate HSI and GSI. Liver weights were not recorded for white suckers because the liver tissue was intertwined with the intestine. The HSI was calculated as $100 \mathrm{X}$ (liver weight/body weight - gonad weight). Condition factor $(\mathrm{KtL})$ was calculated by using the formula $10^{5} \mathrm{X}$ ([body weight - gonad weight $] /$ total length $^{3}$ ). Small pieces of liver (2mm or less), spleen, and anterior kidney were placed into RNAlater ${ }^{\circledR}$ solution for subsequent molecular analyses. Pieces of gill, liver (5 to 8 pieces, each piece 1-1.5 centimeters [cm]), anterior and posterior kidney, spleen, gonad, thyroid and any lesions or abnormalities were placed in Z-Fix ${ }^{\mathrm{TM}}$ (Anatech Ltd, Battle Creek, Minnesota) for subsequent histological analyses. The sagittal otoliths were removed from bass species by removing gill arches and the tissue from the soft pallet on the roof of the mouth. A lateral cut was then made with bone shears across the anterior section of the elongated cartilaginous structure located at the base of the brain cavity, exposing the pair of sagittal otoliths. The lapillus otoliths were removed from brown bullhead and white sucker in a similar manner. Following extraction, all otoliths were placed in a labeled coin envelope for subsequent processing and analysis.

A yeast bioreporter assay was used to determine the presence of chemicals in grab water samples capable of initiating estrogen receptor mediated gene transcription. Other in vitro screening assays were used to measure whether chemicals were present in these water samples that would lead to ligand mediated translocation of the androgen or glucocorticoid receptor from the cytoplasm to the nucleus of reporter cell lines. These analyses were performed on extracted discrete grab samples of water collected in clean amber bottles and stored on ice in fall 2010. Samples were acidified to $\mathrm{pH} 3.0 \mathrm{using}$ hydrochloric acid and stored in glass bottles at $4{ }^{\circ} \mathrm{C}$ prior to extraction.

\section{Laboratory Analysis}

\section{Age Analysis}

Sagittal otoliths were prepared by methods modified from Christensen (1964). Briefly, the whole otolith was cracked transversely using a scalpel. One side of the cracked otolith was burned with an alcohol burner (95\% ethanol), cooled immediately in distilled water, and read using a stereoscope. Lapillus otoliths were prepared using methods modified from Koch and Quist (2007). Whole lapillus otoliths were prepared using a multiple-stage process. First, plastic 2.0 -mL flat-top microcentrifuge tubes (Fisher Scientific, Pittsburgh, Pennsylvania) have their caps filled with modeling clay, and the tapered ends removed to create a cylinder. Singular lapilli were placed into the clay such that the "thumb" of the otoliths was embedded into the clay. The vial was filled using the Epoxicure ${ }^{\circledR}$ brand of resin and hardener (Buehler Inc., Lake Bluff, Illinois) and allowed to harden. The plastic case was then removed and the otoliths sectioned at approximately $0.64 \mathrm{~mm}$ thickness using an Isomet low speed saw (Buehler Inc. Lake Bluff, Ill.). Sections were read under transmitted light using a stereoscope. All age data were collected in a double blind study, meaning that two individuals read each otolith, and the age estimates were independent of biological data.

\section{Reproductive Health Indicators}

Reproductive health indicators consisted of the gonadosomatic index (GSI), plasma vitellogenin concentrations, reproductive hormones, and gonad histology. 


\section{Gonadosomatic Index}

GSI is a ratio of gonad weight to body weight calculated by the formula (gonad weight/[body weight - gonad weight]) X 100.

Vitellogenin

Plasma vitellogenin (Vtg) concentrations were measured using a direct enzyme-linked immunosorbent assay (ELISA). The primary antibodies were monoclonal antibodies, including ND-3G2 (small and largemouth bass), ND-2D3 (white sucker), or 1D12 (brown bullhead) (Cayman Chemical Company, Ann Arbor, Mich.). The Vtg standards used for the assay were purified from smallmouth bass, white sucker or brown bullhead and were prepared at the Center for Human and Environmental Toxicology, University of Florida, Gainesville, Florida. Briefly, plasma samples were diluted 1:1000, 1:5000, 1:10,000, 1:50,000 or 1:100,000 with PBSZ (4.2 millimoles [mM] trisodium phosphate, $5.8 \mathrm{mM}$ monosodium phosphate, $150 \mathrm{mM}$ sodium chloride $(\mathrm{NaCl}), 0.02 \%$ sodium azide, $\mathrm{pH} 7.6$ ). Plasma samples were loaded in duplicate and genera specific Vtg standards were loaded in triplicate at a volume of 50 microliters $(\mu \mathrm{L})$ into a 96-well Easy Wash High Binding plate (Costar, Corning, N.Y.) and stored overnight at $4{ }^{\circ} \mathrm{C}$ in a humidified chamber. Following an overnight incubation the plates were washed five times with Tris-buffered saline and Tween 20 (TBST) (10 mM Sigma 7-9, $150 \mathrm{mM} \mathrm{NaCl,} 0.05 \%$ Tween-20, $\mathrm{pH} 7.6$ ) and $300 \mu \mathrm{L}$ of blocking buffer (10 mM Sigma 7-9, $150 \mathrm{mM} \mathrm{NaCl}, 1 \%$ bovine serum albumin, $0.05 \%$ Tween-20, $\mathrm{pH}$ 7.6) was added. Plates were incubated at room temperature for 1 hour and washed five times with TBST. The anti-Vtg antibody was diluted 1:1000 in blocking buffer, added to all wells, and incubated at room temperature for 1 hour. Plates were then washed five times with TBST. The biotinylated secondary antibody (goat anti mouse IgG-biotin) was diluted 1:1000 in blocking buffer, added to all wells, and incubated at room temperature for 1 hour. Plates were then washed five times with TBST. Strepavidin-alkaline phosphatase was diluted 1:5,000 in blocking buffer, added to all wells and incubated at room temperature for 1 hour. Plates were then washed five times with TBST, and color was developed by adding a development solution (2.7mM 4-nitro-phenyl phosphate, $30 \mathrm{mM}$ sodium carbonate, $2 \mathrm{mM}$ magnesium chloride $\left(\mathrm{MgCl}_{2}, \mathrm{pH}\right.$ 9.6). Plates were incubated at room temperature for 30 minutes. Optical density (405 nanometers [nm]) readings were taken every 10 minutes during this incubation using SpectraMax M4 microplate reader (Molecular Devices, Inc., Sunnyvale, California). Concentrations of the unknowns were determined from the standard curves and using Softmax Pro TM software (Molecular Devices). The limit of detection was 1 microgram per milliliter $(\mu \mathrm{g} / \mathrm{mL})$.

\section{Reproductive Hormones}

Hormones were extracted from $50 \mu \mathrm{L}$ of plasma twice in a ten-fold excess of diethyl ether (Acros Organics, Geel, Belgium), blown to dryness and solubilized in $400 \mu \mathrm{L}$ of room temperature phosphate gelatin (PG) buffer (0.1\% knox gelatin in Dulbecco's phosphate-buffered saline [DPBS]). The sex steroid hormones 17 $\beta$-estradiol and 11-keto testosterone were measured using ELISA-based kits (Cayman Chemical, Ann Arbor, Mich.). Hormone concentrations were measured at $412 \mathrm{~nm}$ with a SpectraMax M4 microplate reader (Molecular Devices, Inc., Sunnyvale, Calif.). Concentrations of the unknowns were determined from the standard curves and using the Softmax Pro TM Program (Molecular Devices). The limits of detection were 20 picograms per milliliter $(\mathrm{pg} / \mathrm{mL})$ for estradiol and $1.3 \mathrm{pg} / \mathrm{mL}$ for $11-$ keto testosterone. 


\section{Gonad Histology}

Five to seven cross-sections of each gonad were placed in cassettes, routinely processed and embedded into paraffin. Blocks were sectioned at 5 micrometers $(\mu \mathrm{m})$ and stained with hematoxylin and eosin. Slides were examined for any abnormalities at the microscopic level. Sections of gonads were used to confirm sex, stage of development, percent atretic eggs, and any other abnormalities such as occurrence of intersex, fibrosis, abnormal yolk accumulation, ceroid/lipofuscin accumulations, or Sertoli cell proliferation and were evaluated after neoplasia as described by Blazer (2002), Leino et al. (2005), and Dietrich and Krieger (2009).

\section{Genotoxic/Mutagenic/Carcinogenic Indicators}

Genotoxic/mutagenic/carcinogenic indicators consist of cell nuclear abnormalities and internal and external neoplasms.

\section{Red Blood Cell Micronuclei and other Nuclear Abnormalities}

Blood smears were stained with Giemsa solution (Fluka Analytical, Saint Louis, Missouri) for 45 minutes, followed by two, 45-minute distilled water baths using methods modified from Carrasco et al. (1990). Stained slides were cover-slipped and evaluated under light microscopy at 600x magnification. A minimum of 200 erythrocytes were examined at five stratified random locations on each slide such that a minimum of 1,000 erythrocytes were evaluated for abnormalities. The abnormalities were recorded as described by Carrasco et al. (1990). Briefly, a micronucleus was defined as a round cytoplasmic intrusion having a diameter one-tenth to one-third that of the primary nucleus. Notched nuclei are indentations extending well into the nuclear envelope. Lobed nuclei have large evaginations of the nuclear envelope with no clear shape or definition. Blebbed nuclei are small evaginations of the nuclear envelope that may resemble a micronucleus, but are attached to the nucleus. A binucleated cell contains two nuclei that are relatively similar in size and not attached.

\section{Proliferative, Preneoplastic and Neoplastic Lesions}

Five to seven pieces of liver, and pieces of spleen, kidney, gill, thyroid and any external or internal abnormalities were placed in Z-Fix ${ }^{\mathrm{TM}}$ in the field. Fixed tissue samples were trimmed, placed in cassettes, processed, and embedded into paraffin. Blocks were sectioned at $5 \mu \mathrm{m}$ and stained with hematoxylin and eosin. Slides were examined for any abnormalities at the microscopic level. One slide for each fish, containing pieces of liver, spleen and anterior kidney, were stained using the Perl' Prussian blue method for iron to differentiate pigments within macrophage aggregates and hepatocytes. The method stains hemosiderin, an iron-containing protein, while melanin remains black, and ceroid/lipofuscin remains yellowish-brown (Luna 1992). Liver sections were examined for preneoplastic and neoplastic lesions as described by Blazer et al. (2006b and 2007a). Other nonneoplastic lesions such as fibrosis, bile duct proliferation, and inflammation (Wolf and Wolfe 2005) were documented. Proliferative skin lesions were identified following the criteria of Blazer et al. (2007a).

\section{Molecular Endpoints}

At the onset of this research, brown bullhead, white sucker, smallmouth bass, and largemouth bass gene sequence databases were sparsely populated. In order to develop primer or probe sets to quantify biomarker gene expression it was critical to construct annotated gene databases for these species. Total RNA was extracted from a total of 20 smallmouth bass or brown bullhead liver samples 
using EZNA total RNA isolation kits (Omega Bio-Tek, Norcross, Georgia). Transcriptome libraries for each species were constructed slightly differently given advances in technology and options during the project. For the brown bullhead and smallmouth bass, total RNA was shipped to CoFactor Genomics (St. Louis, Mo.). Ribosomal RNA was depleted using a Ribo-Zero kit (Epicentre, Madison, Wis.) and samples were normalized with an Evergren normalization kit (Evergen Biotechnologies, Inc., Vernon, Connecticut). RNA-seq, 2 x 6 base pair mate-paired libraries were prepared for each species.

Sequencing was performed on an Illumina GAIIx (Illumina, San Diego, Calif.), and each library was run in a single lane to yield approximately 2.2 gigabytes $(\mathrm{Gb})$ of sequence. An additional smallmouth bass run was performed for transcriptome analysis on total RNA at Duke Institute for Genome Science and Policy (Durham, North Carolina). Samples were sequenced on a Roche 454 GS FLX (Roche, Branford, Conn.). For white suckers, total RNA was pooled from liver tissues $(n=10)$, slightly raised mucoid skin lesions $(n=9)$, raised papilloma-like lip lesions $(n=5)$, and discrete white spots on the skin $(n=8)$. As above, ribosomal RNA was depleted from the samples. The RNA was then shipped to the Institute for Genome Science core laboratory (Baltimore, Maryland) for library preparation and sequencing. RNA-seq libraries were prepared and 100 base pair paired-end reads were achieved on an Illumina HiSeq (Illumina, San Diego, Calif.). Raw sequence reads were assembled using CLC Genomics workbench and biomarker genes were identified via BLASTx analyses to the National Center for Biotechnology (NCBI) RefSeq database for the zebra danio (Danio rerio).

Individual liver samples collected and stabilized in RNA Later ${ }^{\circledR}$ (Life Technologies, Carlsbad, Calif.) were prepared for gene expression analysis using NanoString Analysis. Tissue lysate for analysis was prepared by lysing approximately 20 milligrams (mg) of liver tissue in 400 microliters $(\mu \mathrm{L})$ TRK Lysis Buffer (Omega Bio-tek, Norcross, Ga.). The tissue was homogenized on a TissueLyser (Qiagen, Hilden, Germany) with 5-mm stainless steel beads. Samples were then centrifuged at maximum speed for 10 minutes to remove the insoluble tissue components, and the supernatant and stored at $-80{ }^{\circ} \mathrm{C}$ until shipment. A total of 250 smallmouth bass, 360 largemouth bass, 214 white sucker and 267 brown bullhead samples were processed for gene expression analysis. The nCounter analysis for gene expression was conducted at the Genomics and Proteomics Core Laboratories at the University of Pittsburgh.

Exploratory analysis of smallmouth bass liver gene expression data was performed using NanoStride (http://nanostride.soe.ucsc.edu/) which analyzes NanoString nCounter analysis count data. These analyses included expression data from male and female smallmouth bass collected during spring 2010 and fall 2011 from the St. Louis, Fox and Milwaukee Rivers. Smallmouth bass were not present for collection at the other AOCs. Data files generated from the nCounter analysis were uploaded to compare the differential expression of genes among groups. Samples were normalized to internal housekeeping genes present in the data. Housekeeping genes for this analysis included Ribosomal Protein L8 (RPL8), hypoxanthine phosphoribosyltransferase 1 (hprt1), eukaryotic translation initiation factor 3D (eif3d) and RBMX2. All groups of two were analyzed using the DESeq statistical test which assumes a negative binomial distribution and thus was most appropriate for this type of data. P-values were adjusted following Benjamini and Hochberg (1995). The p-value cut off for the generation of heatmaps was set to 0.05 . Groups of three or more were analyzed using one-way analysis of variance (ANOVA) with adjusted p-values and p-value cut offs as described above.

Additional statistical analysis was needed of the data using the $\mathrm{R}$ statistical software (R Core Team, 2012). Samples were normalized using the NanoStringNorm package (Waggott et al., 2012) and the same four housekeeping genes listed above. Differential expression of genes were then assessed using the bioconductor: edgeR package (Robinson et al., 2010). This method produced results that were similar to those of the NanoStride software and allows the user to adjust test parameters as necessary. 


\section{In vitro Screening Assays of Water Samples}

Water samples were filtered by vacuum filtration through a glass fiber filter. Polar analytes were captured via solid phase extraction (SPE) using OASIS HLB columns (Ciparis et al., 2012). Samples were eluted with methanol and methanol dichloromethane (50:50), concentrated to dryness, and then reconstituted in $100 \%$ methanol. For total estrogenicity, extracts were added to the wells of a 96-well black plate and diluted $90 \%$ in yeast growth medium. The yeast reporter (strain BLYES) was used to determine $17 \beta$-estradiol equivalents of each sample extract. Estradiol standards were included on each plate and estrogenicity of the sample extract determined by interpolation from the E2 standard curve (Sanseverino et al., 2005). In addition, in fall 2010, androgen and glucocorticoid activity was screened using a high-throughput live cell assay based on subcellular relocalization of green fluorescent protein (GFP)-tagged receptors by collaborators in the National Institute of Health National Cancer Institute (Stavreva et al., 2012).

\section{Results and Discussion}

\section{Fish Collection}

Fish were collected at seven AOCs and at one Reference site (Table 1).

Table 1. Sampling site Areas of Concern and locations in the Great Lakes Basin. Latitudes and longitured are in decimal degrees, North American Datum (NAD) 83 Geographic Coordinate System (GCS).

\begin{tabular}{llcc}
\hline \multicolumn{1}{c}{ Area of Concern } & \multicolumn{1}{c}{ Stream Name } & Longitude & Latitude \\
\hline Rochester Embayment & Genesee River & -77.618 & 43.234 \\
St. Louis River & St. Louis Bay & -92.115 & 46.759 \\
Maumee River & Swan Creek & -83.532 & 41.648 \\
Detroit River & Trenton Channel (Detroit River) & -83.159 & 42.177 \\
Fox River/Lower Green Bay & Fox River & -88.005 & 44.539 \\
Milwaukee Estuary & Milwaukee River & -87.911 & 43.032 \\
Ashtabula River & Ashtabula River & -80.795 & 41.900 \\
Reference & Conneaut Creek & -80.545 & 41.965 \\
\hline
\end{tabular}

Fish were collected in fall 2010 from September 21 to October 19 and in spring 2011 from April 12 to May 2. In fall 2010 fish were collected at five AOCs (Table 1). Fish were not collected at the Milwaukee River AOC in fall 2010. In spring 2011 an attempt was made to collect fish at the same sites in order to compare biological effects seasonally. Additionally, fish were collected at the Ashtabula River AOC and Conneaut Creek (reference site) in spring and fall 2011 (Table 2). 
Table 2. Summary of Fishes Collected for Fish Health Assessments in selected Areas of Concern in the Great Lakes Basin, fall 2010 and spring 2011.

[AOC, Area of Concern; M, male; F, female]

\begin{tabular}{|c|c|c|c|c|c|}
\hline Site & Date & $\begin{array}{c}\text { Brown } \\
\text { bullhead }\end{array}$ & $\begin{array}{l}\text { White } \\
\text { sucker }\end{array}$ & $\begin{array}{l}\text { Largemouth } \\
\text { bass }\end{array}$ & $\begin{array}{c}\text { Smallmouth } \\
\text { bass }\end{array}$ \\
\hline $\begin{array}{l}\text { Rochester Embayment AOC } \\
\text { Genesee River }\end{array}$ & $\begin{array}{l}\text { Fall } 2010 \\
\text { Spring } 2011\end{array}$ & $\begin{array}{l}13 \mathrm{~F} \\
7 \mathrm{M}\end{array}$ & & $\begin{array}{c}6 \mathrm{~F} \\
14 \mathrm{M} \\
9 \mathrm{~F} \\
10 \mathrm{M}\end{array}$ & \\
\hline $\begin{array}{l}\text { St. Louis River AOC } \\
\text { St. Louis Bay }\end{array}$ & $\begin{array}{l}\text { Fall } 2010 \\
\text { Spring } 2011\end{array}$ & & $\begin{array}{c}7 \mathrm{~F} \\
7 \mathrm{M} \\
3 \mathrm{~F} \\
22 \mathrm{M}\end{array}$ & & $\begin{array}{c}3 \mathrm{~F} \\
4 \mathrm{M} \\
3 \mathrm{~F} \\
3 \mathrm{M}\end{array}$ \\
\hline $\begin{array}{l}\text { Maumee AOC } \\
\text { Swan Creek }\end{array}$ & $\begin{array}{l}\text { Fall } 2010 \\
\text { Spring } 2011\end{array}$ & & $\begin{array}{c}6 \mathrm{~F} \\
12 \mathrm{M} \\
10 \mathrm{~F} \\
10 \mathrm{M}\end{array}$ & $\begin{array}{c}6 \mathrm{~F} \\
14 \mathrm{M}\end{array}$ & \\
\hline $\begin{array}{c}\text { Detroit River AOC } \\
\text { Trenton Channel }\end{array}$ & $\begin{array}{l}\text { Fall } 2010 \\
\text { Spring } 2011\end{array}$ & $\begin{array}{l}14 \mathrm{~F} \\
6 \mathrm{M}\end{array}$ & $\begin{array}{c}0 \mathrm{~F} \\
20 \mathrm{M}\end{array}$ & $\begin{array}{c}8 \mathrm{~F} \\
12 \mathrm{M} \\
12 \mathrm{~F} \\
8 \mathrm{M}\end{array}$ & \\
\hline $\begin{array}{l}\text { Lower Fox River/Green Bay AOC } \\
\text { Fox River }\end{array}$ & $\begin{array}{l}\text { Fall } 2010 \\
\text { Spring } 2011\end{array}$ & & $\begin{array}{l}18 \mathrm{~F} \\
1 \mathrm{M}\end{array}$ & & $\begin{array}{l}11 \mathrm{~F} \\
9 \mathrm{M} \\
20 \mathrm{~F} \\
0 \mathrm{M}\end{array}$ \\
\hline $\begin{array}{l}\text { Milwaukee Estuary AOC } \\
\text { Milwaukee River }\end{array}$ & Spring 2011 & & $\begin{array}{l}14 \mathrm{~F} \\
6 \mathrm{M}\end{array}$ & & $\begin{array}{l}11 \mathrm{~F} \\
9 \mathrm{M}\end{array}$ \\
\hline $\begin{array}{l}\text { Ashtabula River AOC } \\
\text { Ashtabula River }\end{array}$ & $\begin{array}{l}\text { Spring } 2011 \\
\text { Fall } 2011\end{array}$ & $\begin{array}{c}8 \mathrm{~F} \\
12 \mathrm{M} \\
7 \mathrm{~F} \\
12 \mathrm{M}\end{array}$ & & $\begin{array}{c}8 \mathrm{~F} \\
12 \mathrm{M} \\
10 \mathrm{~F} \\
10 \mathrm{M}\end{array}$ & \\
\hline Conneaut Creek & $\begin{array}{l}\text { Spring } 2011 \\
\text { Fall } 2011\end{array}$ & $\begin{array}{c}9 \mathrm{~F} \\
11 \mathrm{M} \\
10 \mathrm{~F} \\
10 \mathrm{M}\end{array}$ & & $\begin{array}{c}9 \mathrm{~F} \\
11 \mathrm{M}\end{array}$ & \\
\hline
\end{tabular}

Unfortunately, the only seasonal comparisons that could be made were for white suckers collected in St. Louis Bay and Swan Creek, largemouth bass from the Genesse and Detroit Rivers, smallmouth bass from St. Louis Bay (low sample sizes) and the Fox River, and brown bullhead from the Ashtabula River and Conneaut Creek (Table 2). 


\section{Morphometric, Condition Factor and hepotosomatic Index}

\section{Smallmouth and Largemouth Bass}

An acceptable sample size of smallmouth and largemouth bass was obtained at all sites where bass were collected, except for St. Louis Bay where only seven and six smallmouth bass were collected in fall 2010 and spring 2011, respectively. Largemouth bass were collected in both fall and spring from the Genesee and Detroit Rivers, but from Swan Creek only in the fall. Smallmouth and largemouth bass ranged in age from 4 to 14 years (Appendix 1). Swan Creek had the youngest largemouth bass with the lowest condition factors. Condition factors were higher in the spring than in fall at the Genesee and Ashtabula Rivers. At the Genesee, Detroit, and Ashtabula Rivers, largemouth bass had higher HSI in spring than fall (Table 3).

Table 3. Morphometric parameters of largemouth and smallmouth bass collected in the Great Lakes Basin, 201020111

[mm, millimeters; gm, gram; yr, year; n, number]

\begin{tabular}{|c|c|c|c|c|c|c|c|}
\hline Site & Season/year & $\mathbf{N}$ & $\begin{array}{l}\text { Length } \\
(\mathrm{mm})\end{array}$ & $\begin{array}{l}\text { Weight } \\
\text { (gm) }\end{array}$ & $\begin{array}{l}\text { Age } \\
\text { (yr) }\end{array}$ & $\begin{array}{c}\text { Condition } \\
\text { factor }^{2}\end{array}$ & $\begin{array}{c}\text { Hepatosomatic } \\
\text { index }^{3}\end{array}$ \\
\hline \multicolumn{8}{|c|}{ Largemouth Bass } \\
\hline \multirow[t]{2}{*}{ Genesee River } & Fall 2010 & 20 & $330 \pm 10.8$ & $612 \pm 57.0$ & $5.5 \pm 0.1$ & $1.59 \pm 0.04$ & $1.0 \pm 0.1$ \\
\hline & Spring 2011 & 19 & $368 \pm 10.8$ & $906 \pm 95.9$ & $6.7 \pm 0.4$ & $1.64 \pm 0.02$ & $1.9 \pm 0.1$ \\
\hline Swan Creek & Fall 2010 & 20 & $262 \pm 8.0$ & $305 \pm 36.8$ & $4.8 \pm 0.4$ & $1.57 \pm 0.02$ & $1.3 \pm 0.1$ \\
\hline \multirow[t]{2}{*}{ Detroit River } & Fall 2010 & 20 & $355 \pm 13.4$ & $881 \pm 97.4$ & $6.0 \pm 0.3$ & $1.75 \pm 0.04$ & $1.4 \pm 0.1$ \\
\hline & Spring 2011 & 20 & $350 \pm 8.0$ & $731 \pm 51.1$ & $5.4 \pm 0.2$ & $1.58 \pm 0.02$ & $1.8 \pm 0.1$ \\
\hline \multirow[t]{2}{*}{ Ashtabula River } & Spring 2011 & 20 & $374 \pm 11.9$ & $873 \pm 82.0$ & $6.6 \pm 0.4$ & $1.52 \pm 0.03$ & $1.7 \pm 0.1$ \\
\hline & Fall 2011 & 20 & $336 \pm 11.1$ & $608 \pm 72.9$ & $5.7 \pm 0.3$ & $1.46 \pm 0.04$ & $1.3 \pm 0.1$ \\
\hline Conneaut Creek & Fall 2011 & 20 & $339 \pm 9.5$ & $636 \pm 66.8$ & $6.0 \pm 0.5$ & $1.54 \pm 0.03$ & $1.3 \pm 0.1$ \\
\hline \multicolumn{8}{|c|}{ Smallmouth Bass } \\
\hline \multirow[t]{2}{*}{ St. Louis River } & Fall 2010 & 7 & $434 \pm 17.9$ & $1368 \pm 151.8$ & $8.6 \pm 1.2$ & $1.60 \pm 0.03$ & $1.1 \pm 0.1$ \\
\hline & Spring 2011 & 6 & $416 \pm 20.2$ & $1259 \pm 197.1$ & $6.8 \pm 0.6$ & $1.60 \pm 0.10$ & $1.7 \pm 0.3$ \\
\hline \multirow[t]{2}{*}{ Fox River } & Fall 2010 & 20 & $408 \pm 6.2$ & $1098 \pm 96.1$ & $6.1 \pm 0.3$ & $1.76 \pm 0.02$ & $1.7 \pm 0.1$ \\
\hline & Spring 2011 & 20 & $419 \pm 10.2$ & $1185 \pm 77.2$ & $6.1 \pm 0.2$ & $1.49 \pm 0.03$ & $1.7 \pm 0.2$ \\
\hline Milwaukee River & Spring 2011 & 20 & $337 \pm 9.7$ & $522 \pm 79.4$ & $6.4 \pm 0.3$ & $1.26 \pm 0.05$ & $1.7 \pm 0.1$ \\
\hline
\end{tabular}

${ }^{1}$ Data are presented as mean \pm standard error.

${ }^{2}$ Condition factor $(\mathrm{KtL})$ is calculated as ([body weight - gonad weight $] /$ length $\left.{ }^{3}\right) \times 10^{5}$

${ }^{3}$ Hepatosomatic index (HSI) is calculated as (liver weight/[body weight-gonad weight]) X $10^{2}$

Smallmouth bass were collected in the fall and spring from the St. Louis River and the Fox River. There were no differences in the size or age of smallmouth bass from the St. Louis River between fall and spring; however the HSI was higher in the spring than fall. Smallmouth bass from the Fox River did not differ in any parameters between the fall and spring. Although smallmouth bass collected in the Milwaukee River were of similar age to those from the other sites, they were significantly shorter and lighter (Table 3).

\section{White Sucker}

White sucker were collected in fall and spring from St. Louis River and Swan Creek, but only in the fall at Detroit and Fox Rivers and only in the spring from the Milwaukee River. Ages of white sucker ranged from 2 to 16 years (Appendix 1). The Fox and Milwaukee Rivers had the largest and 
oldest suckers with the lowest condition factors. Swan Creen in fall and the Detroit River had the youngest and smallest suckers. The Detroit River suckers had the highest condition factors (Table 4).

Table 4. Morphometric parameters of white sucker collected in the Great Lakes Basin, 2010-20111.

[mm, millimters; gm, gram; yr, year]

\begin{tabular}{llccccc}
\hline \multicolumn{1}{c}{ Site } & \multicolumn{1}{c}{ Season/Year } & $\begin{array}{c}\text { Sample } \\
\text { Size }\end{array}$ & $\begin{array}{c}\text { Length } \\
(\mathbf{m m})\end{array}$ & $\begin{array}{c}\text { Weight } \\
(\mathbf{g m})\end{array}$ & $\begin{array}{c}\text { Age } \\
(\mathbf{y r})\end{array}$ & $\begin{array}{c}\text { Condition } \\
\text { factor }^{2}\end{array}$ \\
\hline St Louis River & Fall 2010 & 14 & $404 \pm 19.7$ & $833 \pm 107.9$ & $7.5 \pm 0.90$ & $1.06 \pm 0.07$ \\
& Spring 2011 & 25 & $402 \pm 6.1$ & $692 \pm 30.8$ & $8.0 \pm 0.47$ & $1.04 \pm 0.01$ \\
Swan Creek & Fall 2010 & 18 & $305 \pm 10.0$ & $318 \pm 33.3$ & $3.9 \pm 0.36$ & $1.06 \pm 0.07$ \\
& Spring 2011 & 20 & $445 \pm 6.4$ & $959 \pm 65.5$ & $7.0 \pm 0.51$ & $1.02 \pm 0.04$ \\
Detroit River & Fall 2010 & 20 & $279 \pm 11.6$ & $254 \pm 17.4$ & $2.7 \pm 0.12$ & $1.13 \pm 0.02$ \\
Fox River & Fall 2010 & 19 & $470 \pm 5.5$ & $906 \pm 48.3$ & $11.8 \pm 0.69$ & $0.83 \pm 0.02$ \\
Milwaukee River & Spring 2011 & 20 & $465 \pm 10.4$ & $1127 \pm 79.4$ & $11.1 \pm 0.51$ & $0.96 \pm 0.02$ \\
\hline
\end{tabular}

${ }^{1}$ Data are presented as mean \pm standard error.

${ }^{2}$ Condition factor $(\mathrm{KtL})$ is calculated as ([body weight - gonad weight $] /$ length $\left.{ }^{3}\right) \times 10^{5}$.

\section{Brown Bullhead}

Brown bullhead were collected at the Genesse and Detroit Rivers only in the spring and from Ashtabula River and Conneaut Creek in spring and fall. Bullhead ranged in age from 3 to 14 years (Appendix 1). Bullhead from the Detroit River were somewhat smaller and younger than those collected from the Genesse River and had higher condition factors and HSI. Mean condition factors were slightly higher at both Ashtabula River and Conneaut Creek in spring versus fall (Table 5).

Table 5. Morphometric parameters of brown bullhead collected in the Great Lakes Basin, 2010-20111.

[mm, millimters; gm, gram; yr, year]

\begin{tabular}{llcccccc}
\hline \multicolumn{1}{c}{ Site } & \multicolumn{1}{c}{$\begin{array}{c}\text { Season/ } \\
\text { Year }\end{array}$} & $\begin{array}{c}\text { Sample } \\
\text { Size }\end{array}$ & $\begin{array}{c}\text { Length } \\
(\mathbf{m m})\end{array}$ & $\begin{array}{c}\text { Weight } \\
(\mathbf{g m})\end{array}$ & $\begin{array}{c}\text { Age } \\
\text { (yr) }\end{array}$ & $\begin{array}{c}\text { Condition } \\
\text { Factor }^{2}\end{array}$ & $\begin{array}{c}\text { Hepatosomatic } \\
\text { Index }^{3}\end{array}$ \\
\hline Genesse River & Spring 2011 & 20 & $319 \pm 11.0$ & $419 \pm 29.8$ & $7.8 \pm 0.6$ & $1.3 \pm 0.03$ & $2.9 \pm 0.2$ \\
Detroit River & Spring 2011 & 20 & $295 \pm 5.1$ & $394 \pm 19.4$ & $5.6 \pm 0.3$ & $1.5 \pm 0.03$ & $3.5 \pm 1.0$ \\
Ashtabula River & Spring 2011 & 20 & $340 \pm 6.5$ & $602 \pm 37.4$ & $7.7 \pm 0.4$ & $1.5 \pm 0.04$ & $3.0 \pm 0.2$ \\
& Fall 2011 & 19 & $311 \pm 8.3$ & $421 \pm 34.5$ & $6.7 \pm 0.5$ & $1.4 \pm 0.03$ & $3.0 \pm 0.1$ \\
Conneaut Creek & Spring 2011 & 20 & $349 \pm 5.1$ & $633 \pm 30.4$ & $7.0 \pm 0.5$ & $1.5 \pm 0.03$ & $2.9 \pm 0.2$ \\
& Fall 2011 & 20 & $336 \pm 8.3$ & $559 \pm 43.6$ & $6.7 \pm 0.3$ & $1.4 \pm 0.03$ & $2.6 \pm 0.1$ \\
\hline
\end{tabular}

${ }^{1}$ Data are presented as mean \pm standard error.

${ }^{2}$ Condition factor (KtL) is calculated as ([body weight - gonad weight $] /$ length ${ }^{3}$ ) X $10^{5}$.

${ }^{3}$ Hepatosomatic index (HSI) is calculated as (liver weight/[body weight-gonad weight]) $\mathrm{X} 10^{2}$.

\section{Gross and Histological Abnormalities}

\section{Smallmouth and Largemouth Bass}

A variety of grossly observable abnormalities were noted externally. The most common external lesions observed in smallmouth and largemouth bass were red raised or eroded areas, melanistic areas (Figure 2A); slightly raised, smooth mucoid lesions (Figure 2B); and opaque or otherwise abnormal eyes. External parasites such as leeches, grubs (cysts containing trematode metacercariae) and black spots (melanocyte accumulation around trematode metacercariae) were observed. 


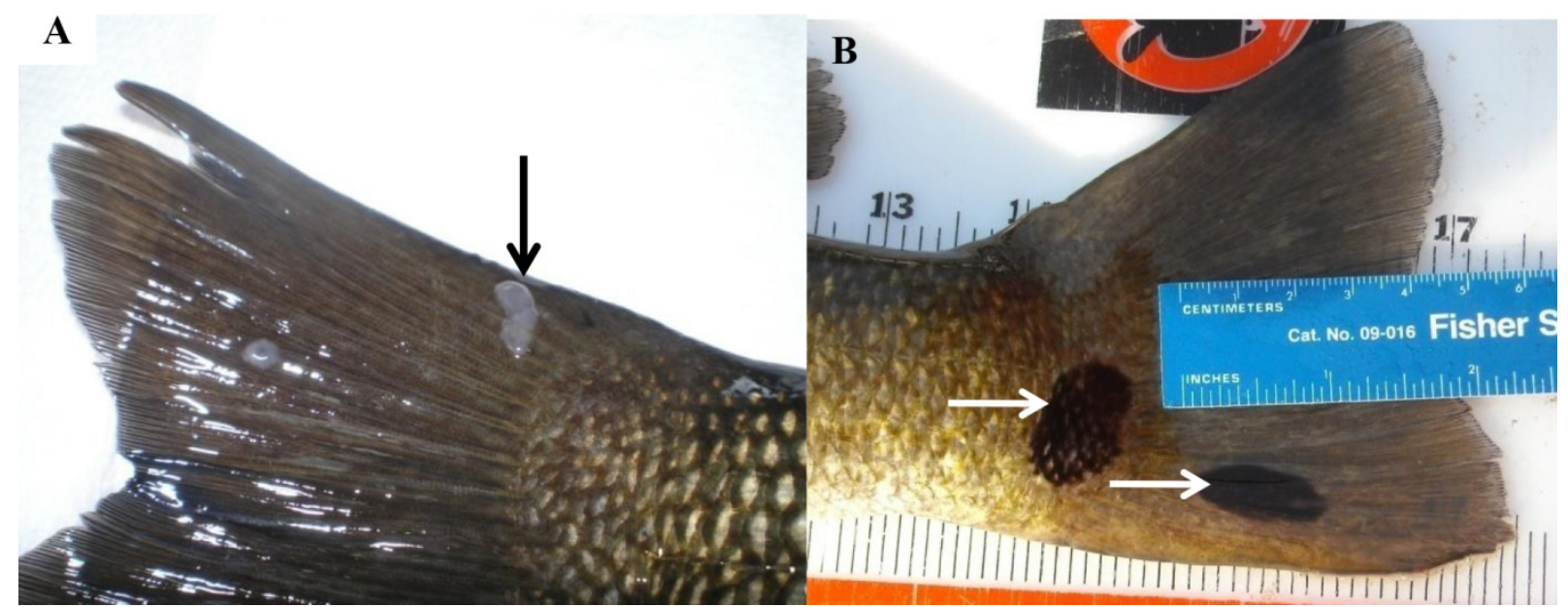

Figure 2. Grossly visible lesions observed on smallmouth and largemouth bass: $A$, slightly raised, mucoid area (arrow) on the caudal fin, and $B$, melanistic areas (arrows) on the caudal fin.

There were site, species, and seasonal differences in the prevalence of the various abnormalities. Eye lesions were observed in at least one smallmouth bass from every site, but were not observed in any largemouth bass from the Detroit River. Red or eroded lesions were observed in both species and were more prevalent in the fall than in the spring (Table 6).

Table 6. Percentage of largemouth and smallmouth bass with visible eye or skin lesions, Great Lakes Basin, 2010-2011.

\begin{tabular}{|c|c|c|c|c|c|c|}
\hline \multirow{2}{*}{ Site } & \multirow{2}{*}{$\begin{array}{c}\text { Season } \\
\text { year }\end{array}$} & \multicolumn{5}{|c|}{ Percentage of individuals with abnormality } \\
\hline & & Eye $^{1}$ & Red/eroded $^{2}$ & Parasites $^{3}$ & Melanistic $^{4}$ & Raised 5 \\
\hline \multicolumn{7}{|c|}{ Largemouth Bass } \\
\hline \multirow[t]{2}{*}{ Genesee River } & Fall 2010 & 5 & 45 & 20 & 25 & 35 \\
\hline & Spring 2011 & 42 & 11 & 16 & 26 & 11 \\
\hline Swan Creek & Fall 2010 & 30 & 25 & 65 & 10 & 10 \\
\hline \multirow[t]{2}{*}{ Detroit River } & Fall 2010 & 0 & 15 & 20 & 30 & 5 \\
\hline & Spring 2011 & 0 & 5 & 0 & 0 & 25 \\
\hline \multirow[t]{2}{*}{ Ashtabula River } & Spring 2011 & 70 & 5 & 30 & 5 & 5 \\
\hline & Fall 2011 & 35 & 15 & 0 & 5 & 15 \\
\hline Conneaut Creek & Fall 2011 & 50 & 45 & 45 & 0 & 10 \\
\hline \multicolumn{7}{|c|}{ Smallmouth Bass } \\
\hline \multirow[t]{2}{*}{ St Louis River } & Fall 2010 & 71 & 29 & 71 & 0 & 28 \\
\hline & Spring 2011 & 33 & 0 & 67 & 0 & 17 \\
\hline Milwaukee River & Spring 2011 & 5 & 15 & 0 & 0 & 5 \\
\hline \multirow[t]{2}{*}{ Fox River } & Fall 2010 & 10 & 25 & 0 & 0 & 10 \\
\hline & Spring 2011 & 5 & 0 & 0 & 10 & 5 \\
\hline
\end{tabular}

${ }^{1}$ Eye abnormalities include opaque, missing, or otherwise abnormal eyes.

${ }^{2}$ Includes eroded, reddened, or raised reddened areas and wounds.

${ }^{3}$ Parasites included leeches, copepods, and trematodes (black spot, grubs).

${ }^{4}$ Melanistic areas are non-raised black areas on body surface, lips, or fins.

${ }^{5}$ Raised lesions on body surface, lips, or fins. 
Microscopically, the red or eroded lesions were generally areas of inflammation and hemorrhage, likely induced by infectious agents (Figure 3A). Parasites, which may damage the skin and cause microwounds, were also more common in the fall. The slightly raised mucoid skin lesions were observed in both species. Histologically, the majority of these lesions were focal areas of hyperplasia (Figure 3B). In one smallmouth from the St. Louis River the mucoid lesion was a papilloma (Figure 3D). Melanistic areas were observed on largemouth bass from all sites, but only on smallmouth bass from the Fox River (Table 6). Normally, melanocytes were located in the dermis of the skin (Figure 3C). Within the melanistic areas there were increased melanocytes in the epidermis, which was sometimes slightly thickened (Figure 3D).

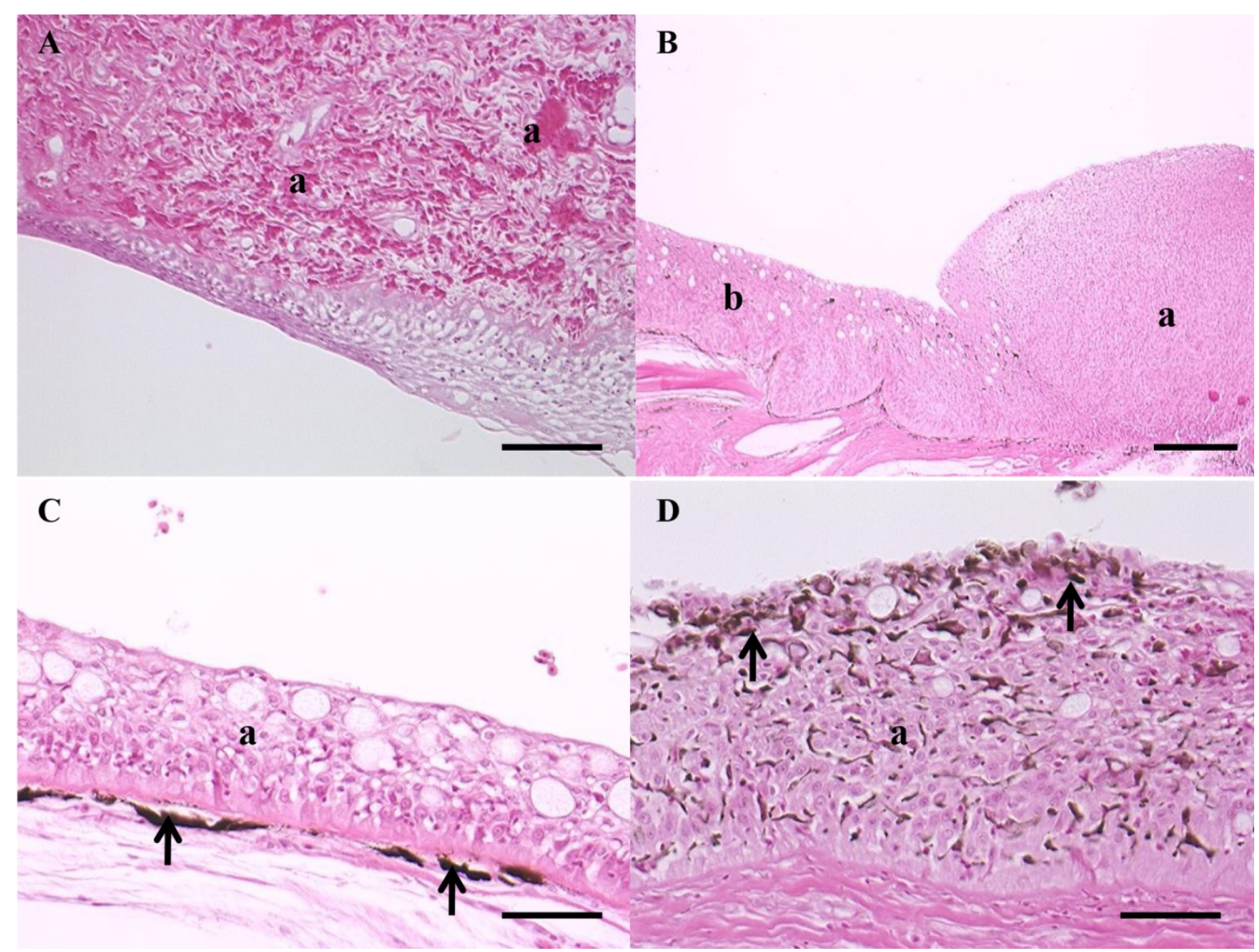

Figure 3. Microscopic pathology of skin lesions observed on bass: $A$, reddened lesion with areas of hemorrhage (a) (scale bar equals 100 micrometers [ $\mu \mathrm{m}]), B$, slightly raised mucoid lesions with an area of hyperplastic epidermis (a) adjacent to normal skin (b) (scale bar equals $200 \mu \mathrm{m}$ ), C, normal skin of bass with epidermis (a) and dermis with melanocytes (arrows), (scale bar equals $50 \mu \mathrm{m} 0$ ), and $D$, microscopic pathology of a melanistic areas with a slightly hyperplastic epidermis (a) containing melanocytes (arrows) (scale bar equals $50 \mu \mathrm{m}$ ).

\section{White Sucker}

The gross lesions on white sucker included reddened eroded lesions, slightly raised mucoid lesions on the fins and body surface, small raised white spots, hard raised nodules, and larger raised lip and body surface lesions (Figure 4). 


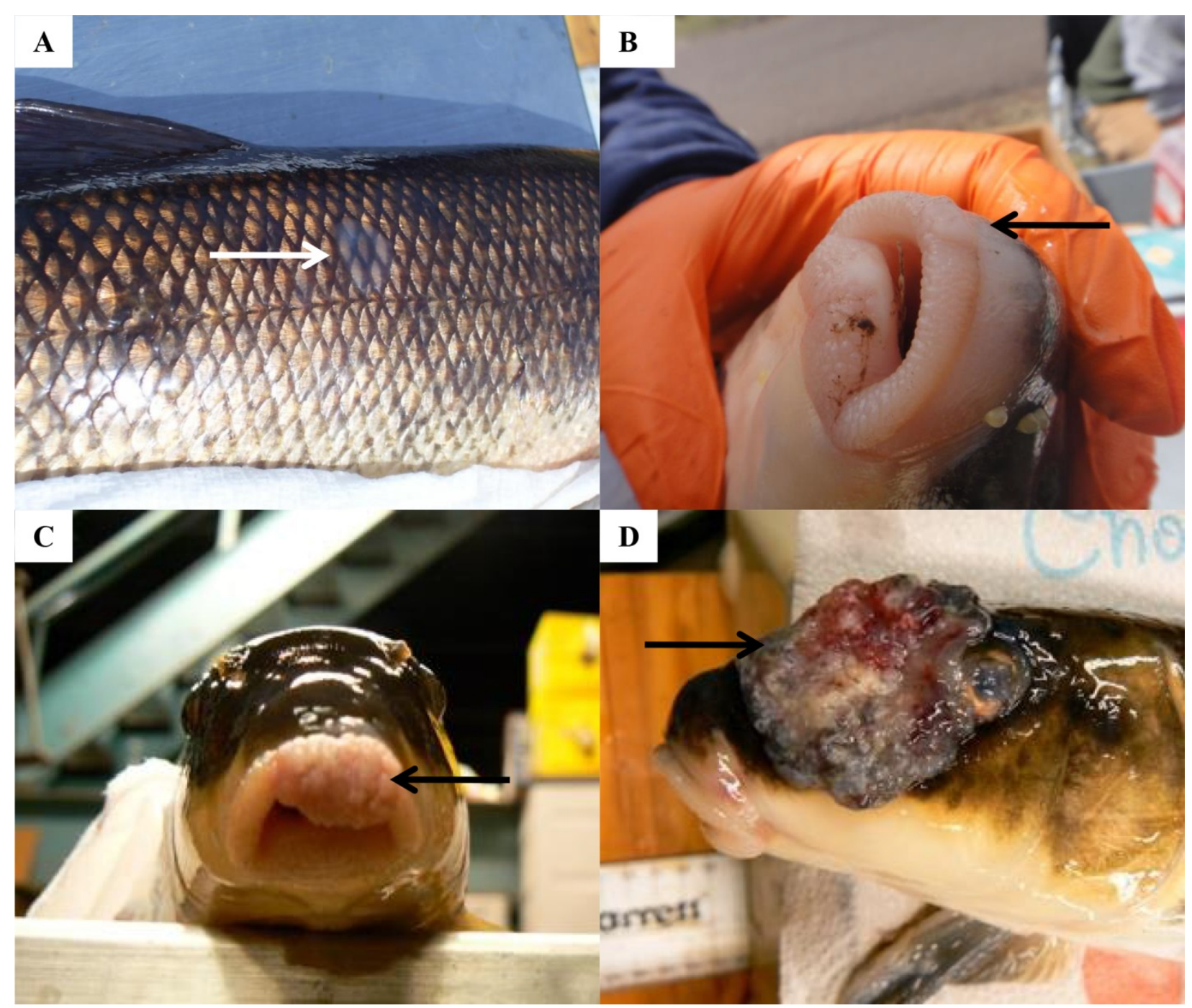

Figure 4. Grossly visible lesions observed on white sucker: $A$, slightly raised, mucoid area (arrow) on the body surface, $B$, slightly raised lip lesion (arrow), $C$, large, papillomatous growth on the lip (arrow), and $D$, large, multicolored growth (arrow) on the head and eye.

In general, white sucker from the Fox and Milwaukee rivers had the highest number of external lesions, including eye abnormalities, red/eroded areas and raised lesions. Seasonal comparisons could be made only for white sucker from St. Louis River and Swan Creek. In the spring, a higher prevalence of raised lesions was noted for white sucker at St. Louis River and of red/eroded lesions for white sucker at Swan Creek were noted (Table 7). 
Table 7. Percentage of white sucker with visible eye or skin lesions, Great Lakes Basin, 2010-2011.

\begin{tabular}{|c|c|c|c|c|c|}
\hline \multirow{2}{*}{ Site } & \multirow{2}{*}{$\begin{array}{l}\text { Season } \\
\text { year }\end{array}$} & \multicolumn{4}{|c|}{ Percentage of individuals with abnormality } \\
\hline & & Eye $^{1}$ & Red/eroded $^{2}$ & Parasites $^{3}$ & Raised $^{4}$ \\
\hline \multirow[t]{2}{*}{ St. Louis River } & Fall 2010 & 7 & 14 & 7 & 14 \\
\hline & Spring 2011 & 4 & 12 & 16 & 56 \\
\hline \multirow[t]{2}{*}{ Swan Creek } & Fall 2010 & 6 & 6 & 0 & 6 \\
\hline & Spring 2011 & 0 & 35 & 0 & 10 \\
\hline Detroit River & Fall 2010 & 0 & 30 & 15 & 10 \\
\hline Fox River & Fall 2010 & 11 & 32 & 11 & 63 \\
\hline Milwaukee River & Spring 2011 & 25 & 30 & 10 & 40 \\
\hline
\end{tabular}

${ }^{1}$ Eye abnormalities include opaque, missing, or otherwise abnormal eyes.

${ }^{2}$ Includes eroded, reddened, or raised reddened areas and wounds.

${ }^{3}$ Parasites included leeches, copepods, and trematodes (black spot, grubs).

${ }^{4}$ Raised lesions on body surface, fins, and lips.

The majority of the slightly raised mucoid lesions were hyperplastic lesions (Figure 5A). The raised lip and body lesions were generally papillomas (Figure 5B), benign skin tumors, although in some cases squamous cell carcinomas were observed (Figures 5C and D). There were differences noted in the types of raised lesions found at sample sites. For instance, although $31 \%$ of the white sucker from the St. Louis AOC had raised lesions, these were primarily slighty raised mucoid lesions. Only $4.5 \%$ were papillomas, the remaining were hyperplastic lesions (Blazer et al. 2014). Conversely, at Milwaukee River, $40 \%$ of white sucker had raised lesions and $35 \%$ were neoplastic lesions, including papilloma and squamous cell carcinoma. More detailed analyses are underway to compare microscopic appearance, gene expression and water/sediment chemical concentrations to better understand the progression and contributing factors for the observed skin lesions. 


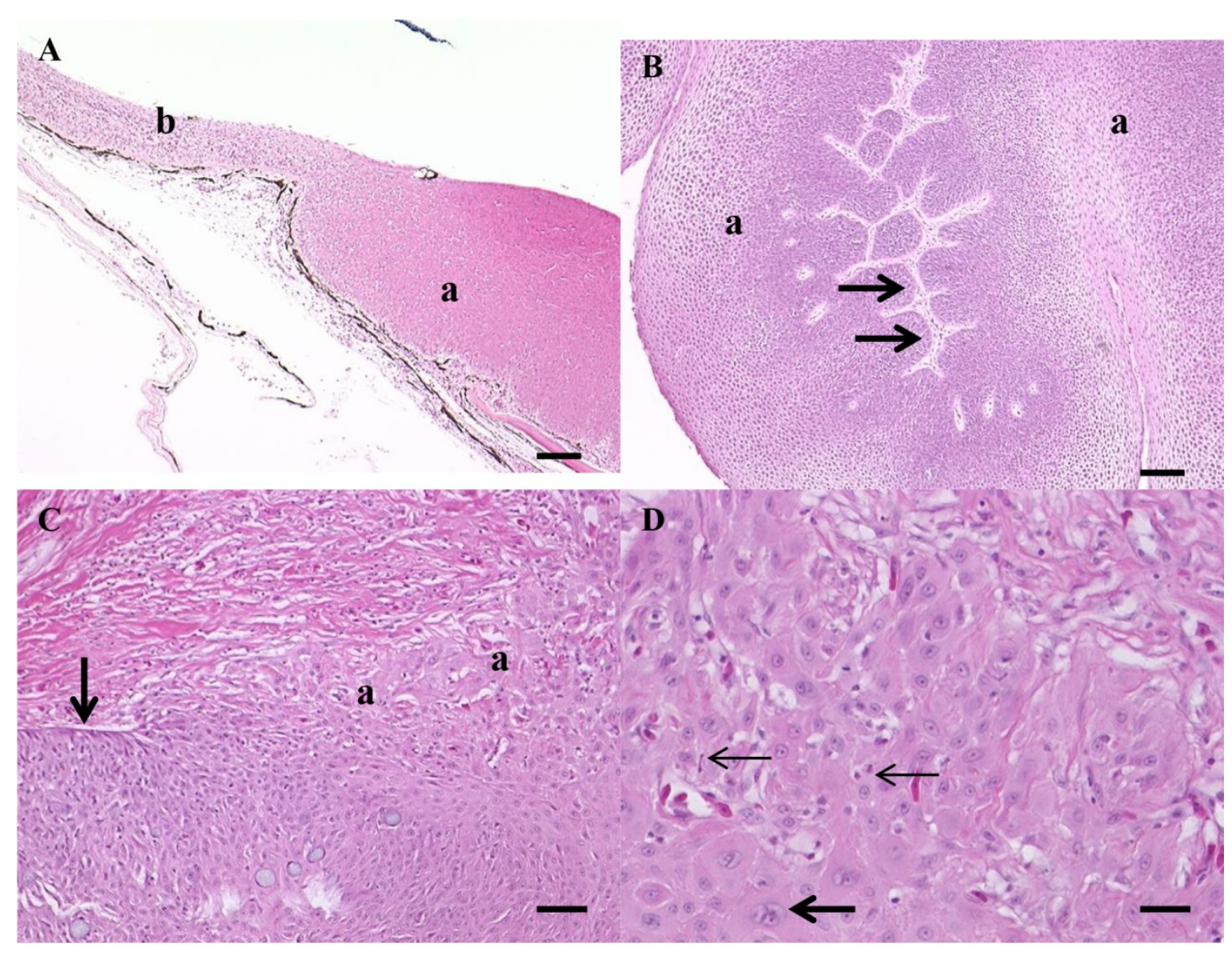

Figure 5. Microscopic pathology of skin lesions observed on white sucker: $A$, slightly raised mucoid lesion with hyperplastic epidermis (a) is thickened in comparison to normal skin (b) (scale bar equals 100 micrometers $[\mu \mathrm{m}]$ ), $B$, papilloma (a) with extensive proliferation of epithelial cells that vary in size and arrangement; neoplastic cells do not extend below the basement membrane (arrows) (scale bar equals $100 \mu \mathrm{m}$ ), C, squamous cell carcinoma with neoplastic epithelial cells (a) infiltrating through the basement membrane (arrow) (scale bar equals $50 \mu \mathrm{m}$ ), and $D$, cells within the squamous cell carcinoma are pleomorphic, may be multinuceate (thick arrow), and have mitotic figures (thin arrow) (scale bar equals $30 \mu \mathrm{m}$ ).

\section{Brown Bullhead}

Lesions observed on brown bullhead included melanistic areas, raised dark lesions on the fins and body surface, and slightly raised to large raised lesions on lips and body surface. Barbel abnormalities were also evaluated in brown bullhead. These included missing, shortened, deformed, and knobbed barbels (with small raised areas) (Figure 6) 


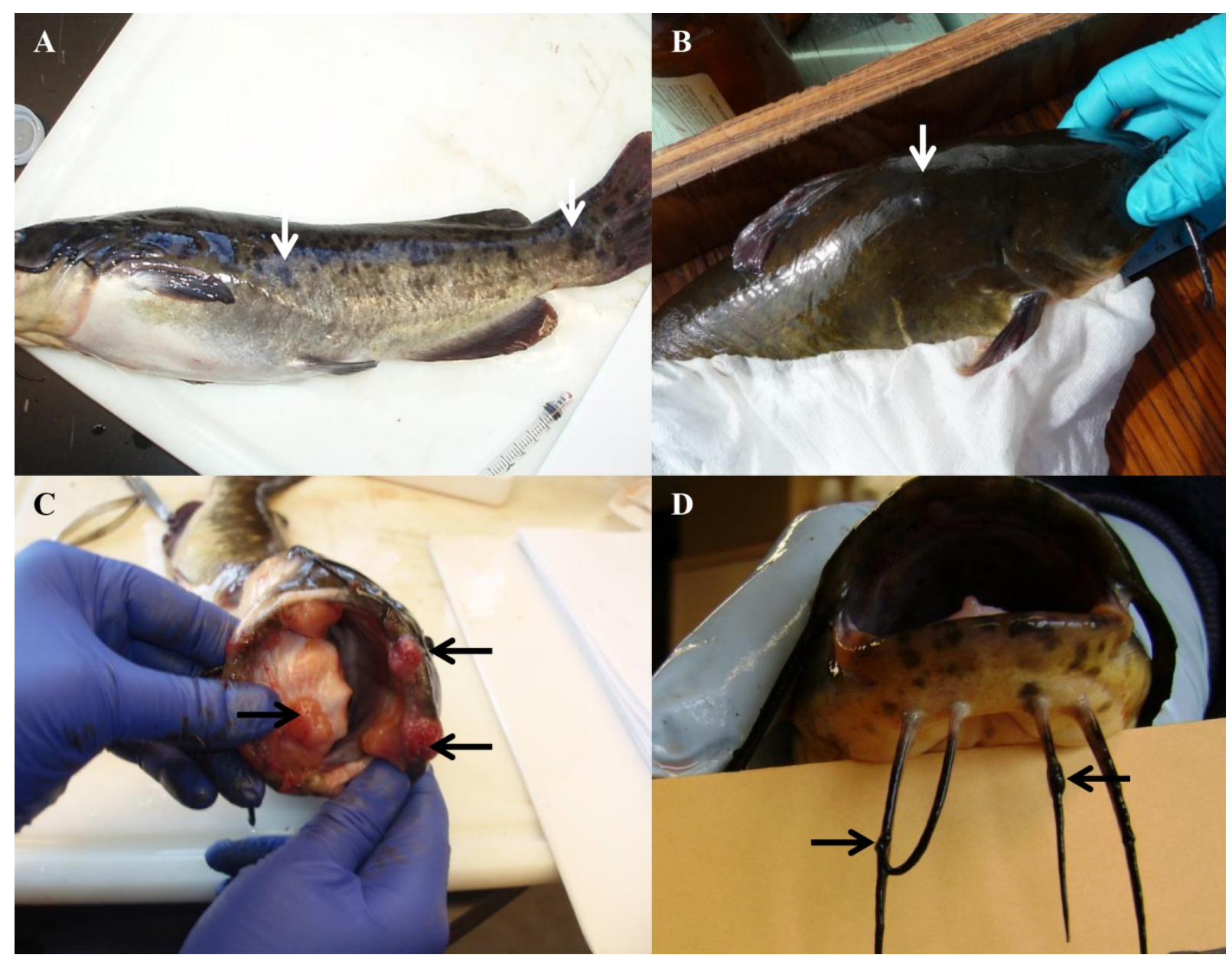

Figure 6. Grossly visible lesions observed on brown bullhead: A, melanistic areas on the body surface (arrows), $B$, raised black nodule (arrow) on the body surface, $C$, mMultiple raised nodules on the lips and mouth (arrows), and $\mathrm{D}$, raised nodules (arrows) on the barbels.

Bullhead from the Genesee and Detroit Rivers had similar incidences of the various abnormalities. Those from Conneaut Creek had the lowest prevalence of raised and melanistic areas but the highest prevalence of red/eroded lesions in both seasons (Table 8). Raised lesions on the lips, body surface or barbels were neoplasms, including papilloma, squamous cell carcinoma, osteoma, and melanoma (previously described in Blazer et al. 2007a). 
Table 8. Percentage of brown bullhead with visible eye, barbel or skin lesions, Great Lakes Basin, 2010-2011.

\begin{tabular}{|c|c|c|c|c|c|c|c|c|}
\hline \multirow{2}{*}{ Site } & \multirow{2}{*}{$\begin{array}{c}\text { Season } \\
\text { year }\end{array}$} & \multicolumn{2}{|c|}{$\begin{array}{c}\text { Barbel } \\
\text { abnormalities }\end{array}$} & \multicolumn{5}{|c|}{ Skin/fin lesions } \\
\hline & & $\begin{array}{l}\text { Raised } \\
\text { areas }\end{array}$ & Other $^{1}$ & Eye $^{2}$ & $\begin{array}{c}\text { Red } / \\
\text { eroded }^{3}\end{array}$ & Parasites $^{4}$ & Melanistic $^{5}$ & Raised $^{6}$ \\
\hline Genesee River & Spring 2011 & 20 & 40 & 0 & 10 & 5 & 45 & 25 \\
\hline Detroit River & Spring 2011 & 35 & 25 & 0 & 5 & 0 & 35 & 20 \\
\hline \multirow[t]{2}{*}{ Ashtabula River } & Spring 2011 & 10 & 35 & 0 & 0 & 0 & 20 & 30 \\
\hline & Fall 2011 & 11 & 0 & 5 & 0 & 0 & 32 & 16 \\
\hline \multirow[t]{2}{*}{ Conneaut Creek } & Spring 2011 & 5 & 10 & 10 & 15 & 0 & 5 & 10 \\
\hline & Fall 2011 & 10 & 30 & 10 & 15 & 15 & 5 & 10 \\
\hline
\end{tabular}

${ }^{1}$ Includes missing, shortened, and deformed barbels.

${ }^{2}$ Eye abnormalities include opaque, missing, or otherwise abnormal eyes.

${ }^{3}$ Includes eroded, reddened or raised reddened areas, and wounds.

${ }^{4}$ Parasites included leeches, copepods, and trematodes (black spot, grubs).

${ }^{5}$ Melanistic areas are non-raised black areas on body surface, lips, or fins.

${ }^{6}$ Raised lesions on body surface, fins, and lips.

\section{Genotoxic/Mutagenic/Carcinogenic Endpoints}

Micronuclei and other nuclear abnormalities of red blood cells, as well as preneoplastic and neoplastic skin and liver microscopic lesions were used as markers of exposure to genotoxic/mutagenic and (or) carcinogenic compounds. Bass generally expressed micronuclei and other nuclear abnormalities ata higher frequency and severity when compared to white sucker or brown bullhead. This micronuclei and other nuclear abnormality data are summarized in Braham (2012). Further analyses are underway to explore the associations between these genotoxic responses, genotoxic or carcinogenic chemical concentrations in water and sediment, and the prevalence and type of various neoplastic and preneoplastic lesions.

\section{Reproductive Endpoints}

In order to address possible reproductive endocrine disruption by exposure to complex mixtures of chemicals, a suite of biological endpoints including GSI, gonad stage, testicular oocyte prevalence and severity, other microscopic gonad abnormalities, plasma vitellogenin, estradiol and 11-ketotestosterone, were measured in each fish. Preliminary analyses of the results indicate exposure to estrogenic or anti-androgenic chemicals. Intersex or testicular oocytes were observed in both smallmouth and largemouth bass, but not in white sucker or brown bullhead. A high percentage of smallmouth bass from both the St. Louis River (low sample size) and Green Bay/Fox River in the fall and also from the St. Louis River in spring (low sample size) had testicular oocytes. Interestingly, no males were collected from Green Bay/Fox River in the spring. Vitellogenin was also measured in some males from these sites. Intersex was not observed in largemouth bass from the Genesse or Detroit Rivers in the fall and vitellogenin was measured at low concentrations in a low percentage of bass from these sites. In the spring, 1 in 10 males from the Genesse River and 2 in 8 males from the Detroit River had testicular oocytes. Interstingly, all the males from these sites had measurable vitellogenin at this time.

Vitellogenin was measured in the fall in some white sucker males, except in the Fox River; however, only one male was collected from the Fox River. Brown bullheads were collected only in the spring from the Genessee and Detroit Rivers, and all males had measurable vitellogenin. Vitellogenin was also measured in all males from the Ashtabula River in spring and fall. 
Further analyses are underway to explore associations of vitellogenin concentrations and intersex prevalence and severity with presence of estrogenic chemicals in water or sediment measured at these sites (Lee et al. 2012), as well as with land use. In addition, the association of these effects with other biological endpoints such as reproductive hormones and gonad histology is being explored.

\section{Molecular Endpoints}

\section{Gene Expression Analysis}

The transcriptome analyses produced a large number of sequences from which custom code set of genes were developed. For smallmouth bass, six housekeeper genes (ribosomal protein L8, hypoxanthine phosphoribosyltransferase 1, eukaryotic translation iniation factor 3D, RBMX2, TATA box binding protein, and $\beta$-actin) were evaluated. Four of these housekeeping genes were identified as suitable candidates for normalization (hypoxanthine phosphoribosyltransferase 1, eukaryotic translation iniation factor 3D, RBMX2, ribosomal protein L8). Forty-four biomarker genes were selected for analysis in individual bass. For brown bullhead, elongation factor $\alpha$, hypoxanthine

phosphoribosyltransferase 1 , tata box binding protein, and eukaryotic translation iniation factor 3D were used as housekeeper genes, and 29 genes were evaluated in individual bullheads. Genes selected for gene expression analysis are listed in Table 9.

Table 9. Genes chosen for NanoString analysis of individual liver samples.

[NA, not applicable]

\begin{tabular}{|c|c|c|}
\hline Bass genes & Brown bullhead genes & White sucker genes \\
\hline Vitellogenin & Vitellogenin & Vitellogenin B1 \\
\hline Estrogen receptors (ER) $\alpha, \beta 1, \beta 2$ & Estrogen receptors $\alpha$ and $\beta$ & G-protein coupled ER 1 \\
\hline Superoxide dismutase & Superoxide dismutase & Superoxide dismutase \\
\hline Heat shock proteins $70,71,90 \alpha$ & Heat shock proteins 70 and $90 \beta$ & Heat shock proteins $90 \beta, 5$ \\
\hline Glutathione peroxidase 1 & Glutathione peroxidase 1 & Glutathione peroxidase 4 \\
\hline Fibroblast growth factor & Fibroblast growth factor & Fibroblast growth factor \\
\hline Glutathione S-Transferase & Glutathione S-transferase & Glutathione S-transferase $\alpha$ \\
\hline Glucokinase & Glucokinase & Glucokinase \\
\hline Thyroid hormone receptors $\alpha, \beta$ & Thyroid hormone receptors $\alpha, \beta$ & Thyroid hormone receptors $\alpha$ \\
\hline Insulin-like growth factor 1 & Insulin-like growth factor 1 & Insulin-like growth factor II \\
\hline CYP1A, CYP3A and CYP17 & CYP1A and CYP3A & CYP1A, CYP3A, CYP2XB \\
\hline Catenin & $\beta$ Catenin & $\beta$ Catenin \\
\hline Aryl hyrdrocarbon receptor & Aryl hyrdrocarbon receptor & Aryl hyrdrocarbon receptor \\
\hline Glucocorticoid receptor & Glucocorticoid receptor & NA \\
\hline Epidermal growth factor receptor & Epidermal growth factor receptor & NA \\
\hline Arginase & Arginase & NA \\
\hline $3 \beta$-Hydroxysteroid dehydrogenase & $3 \beta$-hydroxysteroid dehydrogenase & NA \\
\hline Transforming growth factor $\beta$ & Transforming growth factor $\beta$ & NA \\
\hline Androgen receptor & Androgen receptor & NA \\
\hline Choriogenin & NA & Choriogenin \\
\hline
\end{tabular}


Table 9. Genes chosen for NanoString analysis of individual liver samples — Continued

[NA, not applicable]

\begin{tabular}{|c|c|c|}
\hline Bass genes & Brown bullhead genes & White sucker genes \\
\hline Epoxide hydrolase 1 & NA & Epoxide hydrolase 2 \\
\hline Catalase & NA & Catalase \\
\hline Ferritin & NA & Ferritin \\
\hline Type 1 and II deiodinases & NA & Iodothyronun deiodinase II \\
\hline $\begin{array}{l}\text { Transforming growth factor } \beta \\
\text { Receptor-associated protein } 1\end{array}$ & NA & $\begin{array}{l}\text { Transforming growth factor } \beta \text { Receptor- } \\
\text { associated protein } 1\end{array}$ \\
\hline Apolipoprotein A1 & NA & Apolipoprotein A1 \\
\hline Phosphoenolpyruvate carboxykinase & NA & Phosphoenolpyruvate carboxykinase \\
\hline $\begin{array}{l}\text { Warm temperature acclimation } \\
\text { protein }\end{array}$ & NA & Warm temperature acclimation protein \\
\hline $3-\beta$ hydroxysteroid dehydrogenase & NA & Cytochrome C oxidase III \\
\hline Hepcidins 1 and 2 & NA & 60S Ribosomal protein L7 \\
\hline Elongation factor $1 \alpha$ & NA & Reticluon 1 \\
\hline CYP19A1A (aromatase) & NA & Trypsin \\
\hline Cystenin-rich protein & NA & NA \\
\hline Metallothionein & NA & NA \\
\hline
\end{tabular}

Gene expression profiles were significantly different between male and female smallmouth bass for a number of genes at all sites evaluated for fall 2010 (Table 10) and spring 2011 (Table 11).

Table 10. Regulation in the top 25 target genes between female and male smallmouth bass collected in the Great Lakes Basin in the fall 2010.

[Bold, italicized values are significantly different between the sexes. Positive log2FoldChange values indicate higher expression in females. Mean counts are the average number of transcripts counted per sample. Adjusted P-values were determined according to Benjamini and Hochberg (1995) to account for the false discovery rate. $<$, less than]

\begin{tabular}{lrccc}
\hline \multicolumn{1}{c}{ Gene } & $\begin{array}{r}\text { Mean } \\
\text { counts }\end{array}$ & log $^{2}$ FoldChange & P value & $\begin{array}{c}\text { Adjusted P- } \\
\text { value }\end{array}$ \\
\hline Vitellogenin & $\mathbf{1 5 0 , 5 9 0}$ & $\mathbf{5 . 4 0}$ & $<\mathbf{0 . 0 0 1}$ & $<\mathbf{0 . 0 0 1}$ \\
Choriogenin & $\mathbf{9 , 6 7 9}$ & 4.50 & $<\mathbf{0 . 0 0 1}$ & $<\mathbf{0 . 0 0 1}$ \\
Estrogen receptor alpha & $\mathbf{3 8 2}$ & $\mathbf{5 . 5 7}$ & $<\mathbf{0 . 0 0 1}$ & $<\mathbf{0 . 0 0 1}$ \\
Cystenin-rich protein & $\mathbf{1 8}$ & $\mathbf{2 . 4 2}$ & $<\mathbf{0 . 0 0 1}$ & $<\mathbf{0 . 0 0 1}$ \\
Tata box binding protein & $\mathbf{7 5}$ & $\mathbf{1 . 2 5}$ & $<\mathbf{0 . 0 0 1}$ & $\mathbf{0 . 0 0 3}$ \\
Apolipoprotein A1 & 232,750 & -0.87 & 0.021 & 0.159 \\
Glucocorticoid receptor alpha & 171 & 0.71 & 0.036 & 0.212 \\
Epidermal growth factor receptor & 56 & -0.78 & 0.037 & 0.212 \\
Estrogen receptor beta 1 & 67 & 0.66 & 0.064 & 0.270 \\
Type 1 deiodinase & 31 & 0.93 & 0.070 & 0.270 \\
Transforming growth factor beta receptor 1 & 201 & -0.46 & 0.066 & 0.270 \\
Aryl hyrdrocarbon receptor & 19 & 1.06 & 0.055 & 0.270 \\
Fibroblast growth factor & 38 & -0.72 & 0.083 & 0.295
\end{tabular}


Table 10. Regulation in the top 25 target genes between female and male smallmouth bass collected in the Great Lakes Basin in the fall 2010.-Continued

[Bold, italicized values are significantly different between the sexes. Positive log2FoldChange values indicate higher expression in females. Mean counts are the average number of transcripts counted per sample. Adjusted P-values were determined according to Benjamini and Hochberg (1995) to account for the false discovery rate. $<$, less than]

\begin{tabular}{lrcrc}
\hline \multicolumn{1}{c}{ Gene } & $\begin{array}{c}\text { Mean } \\
\text { counts }\end{array}$ & log $^{2}$ FoldChange & P value & $\begin{array}{c}\text { Adjusted P- } \\
\text { value }\end{array}$ \\
\hline Transforming growth factor beta & 75 & -0.75 & 0.098 & 0.322 \\
Metallotheionen & 1,229 & -0.83 & 0.170 & 0.489 \\
Superoxide dismutase & 185 & 0.44 & 0.243 & 0.531 \\
Androgen receptor alpha & 128 & -0.47 & 0.234 & 0.531 \\
3 beta-hydroxysteroid dehydrogenase & 15 & -0.79 & 0.221 & 0.531 \\
Warm temperature acclimation-related protein & 918 & -0.35 & 0.240 & 0.531 \\
Aromatase & 2 & 0.98 & 0.234 & 0.531 \\
Type II deiodinase & 225 & -0.50 & 0.312 & 0.629 \\
Thyroid hormone receptor alpha & 4 & 0.81 & 0.314 & 0.629 \\
Estrogen receptor beta 2 & 161 & -0.33 & 0.334 & 0.640 \\
Ferritin & 7 & 0.29 & 0.397 & 0.686 \\
B-actin & 5,920 & -0.52 & 0.382 & 0.686 \\
\hline
\end{tabular}

Table 11. Regulation in the top 25 target genes between female and male smallmouth bass collected in the Great Lakes Basin in spring 2011.

[Bold, italicized values are significantly different between the sexes. Positive log2FoldChange values indicate higher expression in females. Mean counts are the average number of transcripts counted per sample. Adjusted P-values were determined according to Benjamini and Hochberg (1995) to account for the false discovery rate. $<$, less than]

\begin{tabular}{lrrrc}
\hline \multicolumn{1}{c}{ Gene } & Mean counts & log$^{2}$ FoldChange & P value & Adjusted P-value \\
\hline Vitellogenin & $\mathbf{2 0 3 , 7 0 6}$ & $\mathbf{1 1 . 7 8}$ & $<\mathbf{0 . 0 0 1}$ & $<\mathbf{0 . 0 0 1}$ \\
Estrogen receptor alpha & $\mathbf{7 0 7}$ & $\mathbf{5 . 4 3}$ & $<\mathbf{0 . 0 0 1}$ & $<\mathbf{0 . 0 0 1}$ \\
Cystenin-rich protein & $\mathbf{2 4}$ & $\mathbf{3 . 1 2}$ & $<\mathbf{0 . 0 0 1}$ & $<\mathbf{0 . 0 0 1}$ \\
Choriogenin & $\mathbf{1 4 , 9 1 9}$ & $\mathbf{6 . 5 5}$ & $<\mathbf{0 . 0 0 1}$ & $<\mathbf{0 . 0 0 1}$ \\
Tata box binding protein & 100 & 1.26 & 0.014 & 0.127 \\
Transforming growth factor beta receptor & 260 & -1.10 & 0.021 & 0.136 \\
Phosphoenolpyruvate carboxykinase & 1,069 & -0.62 & 0.020 & 0.136 \\
CYP1A & 2,004 & -0.70 & 0.025 & 0.143 \\
Androgen receptor alpha & 138 & -0.81 & 0.076 & 0.334 \\
Type II deiodinase & 193 & 0.89 & 0.082 & 0.334 \\
Apolipoprotein A1 & 193,207 & -0.51 & 0.087 & 0.334 \\
Epidermal growth factor receptor & 45 & -0.58 & 0.068 & 0.334 \\
Fibroblast growth factor & 35 & -0.52 & 0.109 & 0.386 \\
Estrogen receptor beta 2 & 250 & -0.70 & 0.159 & 0.522 \\
HSP 70 & 113 & 1.84 & 0.170 & 0.522 \\
Arginase & 326 & 0.75 & 0.211 & 0.606
\end{tabular}


Table 11. Regulation in the top 25 target genes between female and male smallmouth bass collected in the Great Lakes Basin in spring 2011.-Continued

[Bold, italicized values are significantly different between the sexes. Positive log2FoldChange values indicate higher expression in females. Mean counts are the average number of transcripts counted per sample. Adjusted P-values were determined according to Benjamini and Hochberg (1995) to account for the false discovery rate. $<$, less than]

\begin{tabular}{lcccc}
\hline \multicolumn{1}{c}{ Gene } & Mean counts & log $^{2}$ FoldChange & P value & Adjusted P-value \\
\hline Superoxide dismutase & 448 & -0.44 & 0.246 & 0.666 \\
Metallotheionen & 4,254 & -0.57 & 0.307 & 0.743 \\
Beta catenin & 133 & -0.54 & 0.301 & 0.743 \\
Glucocorticoid receptor alpha & 229 & 0.45 & 0.343 & 0.751 \\
Transforming growth factor beta & 74 & -0.47 & 0.341 & 0.751 \\
Glutathione peroxidase 1 & 159 & 0.46 & 0.471 & 0.774 \\
Hepcidin 1 & 19 & 0.34 & 0.385 & 0.774 \\
Ferritin & 9 & 0.51 & 0.462 & 0.774 \\
Aryl hyrdrocarbon receptor & 28 & 0.31 & 0.407 & 0.774 \\
\hline
\end{tabular}

As a result gene expression from males and females was examined separately. Seasonal changes in gene expression were also observed in female (Table 12) smallmouth bass but not in males. More detailed site analyses, species comparisons, and associations of gene expression with other biological endpoints are underway.

Table 12. Regulation of the top 25 target genes between seasons, fall 2010 and spring 2011, in female smallmouth bass collected in the Great Lakes Basin.

[Bold, italicized values are significantly different between seasons. Positive log2FoldChange values indicate higher expression in the Fall. Mean counts are the average number of transcripts counted per sample. Adjusted P-values were determined according to Benjamini and Hochberg (1995) to account for the false discovery rate]

\begin{tabular}{|c|c|c|c|c|}
\hline Gene & $\begin{array}{l}\text { Mean } \\
\text { counts }\end{array}$ & $\log ^{2}$ FoldChange & $P$ value & Adjusted P-value \\
\hline Warm temperature acclimation-related protein & 5,998 & 3.47 & $<0.001$ & 0.006 \\
\hline Type 1 deiodinase & 78 & 1.34 & 0.001 & 0.012 \\
\hline Heat shock protein 70 & 80 & 4.13 & 0.001 & 0.018 \\
\hline Arginase & 229 & 1.85 & 0.011 & 0.125 \\
\hline Glucokinase & 434 & -2.34 & 0.021 & 0.191 \\
\hline Superoxide dismutase & 316 & 0.81 & 0.050 & 0.380 \\
\hline Metallotheionen & 2,567 & 1.94 & 0.117 & 0.766 \\
\hline Cytochrome P450 3A & 733 & -0.46 & 0.135 & 0.776 \\
\hline Insulin-like growth factor 1 & 397 & -0.40 & 0.194 & 0.991 \\
\hline Glutathione peroxidase 1 & 147 & 0.07 & 0.911 & 1.000 \\
\hline Hepcidin 1 & 18 & -0.13 & 0.939 & 1.000 \\
\hline Ferritin & 9 & -0.04 & 0.894 & 1.000 \\
\hline Estrogen receptor alpha & 752 & 0.23 & 0.567 & 1.000 \\
\hline B-actin & 5,698 & -0.13 & 0.939 & 1.000 \\
\hline CYP17 & 4 & 0.85 & 0.313 & 1.000 \\
\hline
\end{tabular}


Table 12. Regulation of the top 25 target genes between seasons, fall 2010 and spring 2011, in female smallmouth bass collected in the Great Lakes Basin. - Continued

[Bold, italicized values are significantly different between seasons. Positive log2FoldChange values indicate higher expression in the Fall. Mean counts are the average number of transcripts counted per sample. Adjusted P-values were determined according to Benjamini and Hochberg (1995) to account for the false discovery rate]

\begin{tabular}{lrcrc}
\hline \multicolumn{1}{c}{ Gene } & $\begin{array}{c}\text { Mean } \\
\text { counts }\end{array}$ & log $^{2}$ FoldChange & P value & Adjusted P-value \\
\hline Glucocorticoid receptor alpha & 211 & 0.02 & 1.000 & 1.000 \\
Catalase & 2,014 & 0.17 & 0.852 & 1.000 \\
Transforming growth factor beta & 64 & -0.24 & 0.955 & 1.000 \\
Choriogenin & 16,688 & -0.05 & 0.934 & 1.000 \\
Androgen receptor alpha & 111 & -0.28 & 0.694 & 1.000 \\
Cystenin-rich protein & 28 & -0.15 & 0.930 & 1.000 \\
Estrogen receptor beta 1 & 81 & -0.06 & 0.956 & 1.000 \\
Transforming growth factor beta receptor 1 & 182 & 0.03 & 0.735 & 1.000 \\
Vitellogenin & 241,913 & -0.26 & 0.515 & 1.000 \\
Heat shock protein 90A & 2,393 & -0.11 & 0.622 & 1.000 \\
\hline
\end{tabular}

\section{Water Analysis}

The data from water analysis were used as part of a larger study documenting the presence of androgenic and glucocorticoid activity in watersheds throughout the Northeast and Great Lakes regions of the United States. Results are discussed in (Stavreva et al. 2012).

\section{Summary and Conclusions}

The major objective of research for this study was to determine whether there were adverse effects on wild fish species in the Areas of Concern (AOCs) in the Great Lakes Basin . The suite of biological responses chosen was useful in comparing species, and site and seasonal differences. The biological responses indicate potential exposures to chemical contaminants leading to adverse effects on fish health. Species differences were obvious. For instance, bass appear to be more sensitive to induction of testicular oocytes, whereas all three species showed induction of vitellogenin in males. Brown bullhead and white sucker were more susceptible to tumor induction, both skin and liver, than were bass. The low sample sizes, particularly for responses that were sex and (or) age related, or related to reproductive (gonad) stage, do not allow for any definitive conclusions on the effects on fish populations or site differences. The wide geographical area included in this initial study led to difficulty in the collection of fish at the same stage of gonadal development, particularly in spring. Further analyses are necessary to understand individual responses, such as intersex or plasma vitellogenin, in regards to gonad stage, season, and reproductive hormone concentrations. Additional research is needed to determine factors contributing to these effects and identify sources. Further studies should be conducted that examine potential contributing factors, such as viruses, parasites, specific chemicals or chemical mixtures, that may be associated with the neoplasms and putative preneoplastic changes observed in skin, liver and testes. In order to remediate or restore habitat for healthy fish populations, it will be necessary to understand the risk factors and pathogenesis of the various lesions observed. This will require chemical analyses of the individual tissues in conjunction with histopathological analyses and gene expression. 


\section{References Cited}

Al-Sabti, K., and Metcalfe, C. D., 1995, Fish micronuclei for assessing genotoxicity in water: Mutation Research, v. 343, p. 121-135.

Au, D.W.T., 2004, The application of histo-cytopathological biomarkers in marine pollution monitoring: a review: Marine Pollution Bulletin, v. 48, p. 817-834.

Ayllón, F., Garcia-Vazquez, E., 2001, Micronuclei and other nuclear lesions as genotoxicity indicators in rainbow trout Oncorhynchus mykiss: Ecotoxicology and Environmental Safety, v. 49, p. 221-225.

Baumann, P.C., Smith, I.R., and Metcalfe, C.D., 1996, Linkages between chemical contaminants and tumors in benthic Great Lakes fish: Journal of Great Lakes Research, v. 22, p. 131-152.

Benjamini, Y., and Hochberg, Y. 1995, Controlling the false discovery rate: A practical and powerful approach to multiple testing: Journal of the Royal Statistical Society Series B, v. 57, p. 289-300.

Blair, B.D., Crago, J.P., Hedman, C.J., and Klaper, R.D., 2013, Pharmaceuticals and personal care products found in the Great Lakes above concentrations of environmental concern: Chemosphere, v. 93 , p. $216-2123$.

Blazer, V.S., 2002, Histological assessment of gonadal tissue in wild fishes: Fish Physiology and Biochemistry, v. 26, p. 85-101.

Blazer, V.S., Fournie, J.W., Wolf, J.C., and Wolfe, M.J., 2006b, Diagnostic criteria for proliferative liver lesions in the Brown Bullhead (Ameiurus nebulosus): Diseases of Aquatic Organisms, v. 72, p. 19-30.

Blazer, V.S., Fournie, J.W., Wolf, J.C., and Wolfe, M.J., 2007a, Manual for the microscopic diagnosis of proliferative liver and skin lesions in the brown bullhead (Ameiurus nebulosus), accessed October 28, 2013 at http://seagrant.psu.edu/publications/technicaldocs/ histofieldmanual.pdf

Blazer, V.S., Hoffman, J., Walsh, H.L., Braham, R.P., Hahn, C., Collins, P., Jorgenson, Z., and Ledder, T., 2014, Health of White Sucker within the St. Louis River Area of Concern associated with habitat usage as assessed using stable isotopes: Ecotoxicology DOI 10.1007/510646-013-1167-5.

Blazer, V.S., Iwanowicz, L.R., and Baumann, P.C., 2006a, Fish health study Ashtabula river natural resource damage assessment. U.S. Geological Survey, OFR2006-1137, accessed December 15, 2013 at http://pubs.er.usgs.gov/publication/ofr20061137.

Blazer, V.S., Iwanowicz, L.R., Henderson, H., Mazik, P.M., Jenkins, J.A., Alvarez, D.A., and Young, J.A., 2012, Reproductive endocrine disruption in Smallmouth Bass (Micropterus dolomieu) in the Potomac River Basin: Spatial and temporal comparisons of biological effects: Environmental Monitoring and Assessment, v. 184, p. 4309-4334.

Blazer, V.S., Iwanowicz, L..R., Iwanowicz, D.D., Smith, D.R., Young, J.A., Hedrick, J. D., Foster, S. W., and Reeser, S. J., 2007b, Intersex (testicular oocytes) in Smallmouth Bass Micropterus dolomieu from the Potomac River and selected nearby drainages: Journal of Aquatic Animal Health, v. 19, p. 242-253.

Blazer, V.S., Rafferty, S.D., Baumman, P.C., Smith, S.B., and Obert, E.C., 2009a, Assessment of the "tumors or other deformities" beneficial use impairment in brown bullhead: I. Orocutaneous tumors: Journal of Great Lakes Research, v. 35, p. 517-526.

Blazer, V.S., Rafferty, S.D., Baumman, P.C., Smith, S.B., and Obert, E.C., 2009b, Assessment of the "tumors and other deformities" beneficial use impairment in brown bullhead: II. Liver tumors: Journal of Great Lakes Research, v. 35, p. 527-537.

Bowron, L.K., Munkittrick, K.R., McMaster, M.E., Tetreault, G., and Hewitt, L.M., 2009. Responses of white sucker (Catostomus commersoni) to 20 years of process and waste treatment changes at a bleached kraft mill, and to mill shutdown: Aquatic Toxicolology, v. 95, p. 117-132. 
Braham, R.P., 2012, An evaluation of the occurrence of micronuclei and other nuclear abnormalities in fishes from the Great Lakes basin, United States: Morgantown, West Virginia, West Virginia University, unpublished M.S. thesis, $79 \mathrm{p}$.

Carrasco, K. R., Tilbury, K.L. and Myers, M.S., 1990, Assessment of the piscine micronuceus test as an in situ biological indicator of chemical contaminants effects: Canadian Journal of Fisheries and Aquatic Sciences, v. 47, p. 2123-2136.

Chamberland, K., Lindroth, B.A., and Whitaker, B., 2002, Genotoxicity in Androscoggin River smallmouth bass: Northeastern Naturalist, v. 92, p. 203-212.

Cheek, A.O., Brouwer, T.H., Carroll, S., Manning, S., McLachlan, J.A., and Brouwer, M., 2001, Experimental evaluation of vitellogenin as a predictive biomarker for reproductive disruption: Environmental Health Perspectives, v. 109, p. 681-690.

Cheshenko, K., Pakdel, F., Segner, H., Kah, O., and Eggen, R.I., 2008, Interference of endocrine disrupting chemicals with aromatase CYP19 expression or activity, and consequences for reproduction of teleost fish: General and Comparative Endocrinology, v. 155, p. 31-62.

Christensen, J. M., 1964. Burning of otoliths, a technique for age determination of soles and other fish: ICES Journal of Marine Sciences, v. 29, p. 73-81.

Ciparis, S., Iwanowicz, L.R., and Voshell, J.R., 2012, Effects of watershed densities of animal feeding operations on nutrient concentrations and estrogenic activity in agricultural streams: Science of the Total Environment, v. 414, p. 268-276.

Denslow, N.D., Chow, M.C., Kroll, K.J., and Green, L., 1999, Vitellogenin as a biomarker of exposure for estrogen or estrogen mimics: Ecotoxicology, v. 8, p. 385-398.

Dietrich, D.R., and Krieger, H.O., 2009, Histological Analysis of Endocrine Disruptive Effects in Small Laboratory Fish: Hoboken, N.J., John Wiley \& Sons, Inc., p. 341.

Ekman, D.R., Ankley, G.T., Blazer, V.S., Collette, T.W., Garcia-Reyero, N., Iwanowicz, L.R., Jorgenson, Z., Lee, K., Mazik, P.M., Miller, D., Perkins, E.J., Smith, E., Tietge, J., Trowbridge, A., amd Villeneuve, D.L., 2013, Biological effects-based tools for monitoring impacted surface water in the Great Lakes: A multiagency research program in support of the GLRI. Environmental Practice, v. 15, p. 409-426.

Ferguson, P.J., Bernot, M.J., Doll, J.C., and Lauer, T.E., 2013, Detection of pharmaceuticals and personal care products (PPCPs) in near-shore habitats of southern Lake Michigan: Science of the Total Environment, v. 458-460, p. 187-196.

Fournie, J.W., Summers, J.K., and Weisberg, S.B., 1996, Prevalence of gross pathological abnormalities in estuarine fishes: Transactions of the American Fisheries Society, v. 125, p. 581-590.

Goede, R.W., and Barton, B.A., 1990, Organismic indices and an autopsy-based assessment as indicators of health and condition of fish, in Adams, S.M., ed., Biological Indicators of Stress in Fish: American Fisheries Society Symposium 8, American Fisheries Society, Bethesda, MD, p. 93-108.

Hassanin, A., Kuwahara, S., Tsukamoyo, Y., Ogawa, K., Hiramatsu, K., and Sasaki, F., 2002, Gonadosomatic index and testis morphology of common carp (Cyprinus carpio) in rivers contaminanted with estrogenic chemicals: Journal of Veterinary Medical Science, v. 64, p. 921-926.

Hayes M.A., Smith, I.R., Rushmore, T.H., Crane, T.L., Thorn, C., Kocal, T.E., and Ferguson, H.W., 1990, Pathogenesis of skin and liver neoplasms in white suckers from industrially polluted areas in Lake Ontario: Science of the Total Environment, v. 94, p. 105-123.

Hinck, J.E., Blazer, V.S., Schmitt, C.J., Papoulias, D.M., and Tillitt, D.E., 2009, Widespread occurrence of intersex in black basses (Micropterus spp.) from U.S. rivers, 1995-2004: Aquatic Toxicology, v. 95 , p. $60-70$. 
Hinck, J.E., Blazer, V.S., Denslow, N.D., Echols, K.R., Gale, R.W., May, T.W., Claunch, R., Wieser, C., Anderson, P.J., Coyle, J.J., Gross, T.S., and Tillitt, D.E., 2007, Biomonitoring of environmental status and trend (BEST) program: Environmental contaminants, health indicators, and reproductive biomarkers in fish from Mobile, Apalachicola-Chattahoochee-Flint, Savannah, and Pee Dee River basins: U.S. Geological Survey Scientific Investigations Report 2007-5176, p. 114.

International Joint Commission, 1991, Commission approves list/delist criteria for Great Lakes Areas of Concern: Fos on International Joint Commission Activities, v. 16, p. 1-5, accessed October 30, 2013 at http://www.ijc.org/php/publications/html/listdelist/index.html.

International Joint Commission, 2009, Great Lakes Chemical of Emerging Concern Advisory workgroup: Great Lakes Water Quality Agreement Priorities 2007-2009 series, Special Publication 2009-01, Winsor, Ontario, Canada, accessed October 30, 2013, at http:/www.ijc.org/en/priorities/ 2009/chemical.

Iwanowicz, L.R., Blazer, V.S., Guy, C.P., Pinkney, A.E., Mullican, J., and Alvarez, D.A., 2009, Reproductive health of bass in the Potomac, USA, drainage: Part 1. Exploring the effects of proximity to wastewater treatment plant effluent: Environmental Toxicology and Chemistry, v. 28, p. $1072-1083$.

Iwanowicz, L.R., Blazer, V.S., Hitt, N.P., McCormick, S.D., DeVault, D.S., and Ottinger, C.A., 2012 , Histologic, immunologic and endocrine biomarkers indicate contaminant effects in fishes of the Ashtabula River: Ecotoxicology, v. 21, p. 165-182.

Jobling, S., Sheahan, D., Osborne, J.A., Matthiessen, P., and Sumpter, J.P., 1996, Inhibition of testicular growth in rainbow trout (Oncorhynchus mykiss) exposed to estrogenic alkylphenolic chemicals:

Environmental Toxicology and Chemistry, v. 15, p. 194-202.

Jobling, S., Nolan, M., Tyler, C.R., Brighty, G., and Sumpter, J.P., 1998, Widespread sexual disruption in wild fish: Environmental Science and Technology, v. 32, p. 2498-2506.

Klaper, R., and Welch, L.C., 2011, Emerging contaminant threats and the Great Lakes: Existing science, existing science, estimating relative risk and determining policy. Alliance for the Great Lakes, accessed November 5, 2013 at http://www.greatlakes.org/Document.Doc?id=1072.

Klečka, G., Persoon, C., and Currie, R., 2010, Chemicals of emerging concern in the Great Lakes Basin: An analysis of environmental exposures: Reviews of Environmental Contamination and Toxicology, v. 207, p. 1-93.

Koch, J.D., and Quist, M.C., 2007, A technique for preparing fin rays and spines for age and growth analysis: North American Journal of Fisheries Management, v. 27, p. 782-784.

Lee, K.E., Langer, S.K., Menheer, M.A., Foreman, W.T., Furlong, E.T., and Smith. S.G., 2012. Chemicals of emerging concern in water and bottom sediment in Great Lakes areas of concern, 2010 to 2011 - Collection methods, analytical methods, quality assurance, and data: U.S. Geological Survey Data Series 723, p. 26.

Leino, R.L., Jensen, K.M., and Ankley, G.T., 2005, Gonadal histology and characteristic histopathology associated with endocrine disruption in the adult fathead minnow (Pimephales promelas): Environmental Toxicology and Pharmacology, v. 19, p. 85-98.

Li H., Helm, P.A., and Metcalfe, C.D., 2010, Sampling in the Great Lakes for pharmaceuticals, personal care products, and endocrine-disrupting substances using the passive polar organic chemical integrative sampler: Environmental Toxicology and Chemistry, v. 29, p. 751-762.

Lingenfelser, S.F., Dallas, C.E., Jagoe, C.H., Smith, M.H., Brisbin, I.L., and Chesser, R.K., 1997, Variation in DNA content of blood cells of largemouth bass from contaminated and uncontaminated waters: Environmental Toxicology and Chemistry, v. 16, p. 2136-2143. 
Luna, L.G., 1992, Histopathologic methods and color atlas of special stains and tissue artifacts: Gaitheresburg, Md., American Histolabs, Inc., p. 767.

Lyons, B.P., Stentiford, G.D., Green, M., Bignell, J., Bateman, K., Feist, S.W., Goodsir, F., Reynolds, W.J., and Thain, J.E., 2004, DNA adduct analysis and histopathological biomarkers in European flounder (Platichthys flesus) sampled from UK estuaries: Mutation Research - Fundamental and Molecular Mechanisms of Mutagenesis, v. 552, p. 177-186.

Metcalfe, C.D., 1988, Induction of micronuclei and nuclear abnormalities in the erythrocytes of mudminnows (Umbra limi) and brown bullheads (Ictalurus nebulosus): Bulletin of Environmental Contamination and Toxicology, v. 40, p. 489-495.

Metcalfe, C.D., Miao, X.-S., Koenig, B.G., and Struger, J. 2003, Distribution of acidic and neutral drugs in surface waters near sewage treatment plants in the lower Great Lakes, Canada: Environmental Toxicolicolgy and Chemistry, v. 22, p. 2881-2889.

Miller, D.H., Jensen, K.M., Villeneuve, D.L., Kahl, M.D., Makynen, E.A., Durhan, E.J., and Ankley, G.T., 2007, Linkage of biochemical responses to population-level effects: a case study with vitellogenin in the fathead minnow (Pimephales promelas): Environmental Toxicology and Chemistry, v. 26, p. 521-527.

Munkittrick, K.R., McMaster, M.E., McCarthy, L.H., Servos, M.R., and Van Der Kraak, G.J., 1998, An overview of recent studies on the potential of pulp-mill effluents to alter reproductive parameters in fish: Journal of Toxicology and Environmental Health, v. 1, p. 347-371.

Munkittrick, K.R., and Dixon, D.G., 1989, Use of white sucker (Catostomus commersoni) populations to assess the health of aquatic ecosystems exposed to low-level contaminant stress: Canadian Journal of Fisheries and Aquatic Sciences, v. 46, p. 1455-1462.

Myers, M.S., and Fournie, J.W., 2002, Histopathological biomarkers as integrators of anthropogenic and environmental stressors, in Adams, S.M. ed., Biological indicators of aquatic ecosystem stress: Bethesda, Md., American Fisheries Society, p. 221-287.

Pinkney A.E, Harshbarger, J.C., Karouna-Renier, N.K., Jenko, K., Balk, L., Skarphéðinsdóttir, H., Liewenborg, B., and Rutter, M.A., 2011, Tumor prevalence and biomarkers of genotoxicity in brown bullhead (Ameiurus nebulosus) in Chesapeake Bay tributaries: Science of the Total Environment, v. 410-411, p. 248-257.

Premdas, P.D., Metcalfe, T.L., Bailey, M.E., and Metcalfe, C.D., 1995, The prevalence and histological appearance of lip papillomas in white sucker (Catostomus commersoni) from two sites in central Ontario, Canada: Journal of Great Lakes Research, v. 21, p. 207-218.

Rafferty S.D., Blazer, V.S., Pinkney, A.E., Grazio, J.L., Obert, E.C., and Boughton, L., 2009, A historic perspective on the "fish tumors or other deformities" beneficial use impairment at Great Lakes Areas of Concern: Journal of Great Lake Research, v. 35, p. 496-506.

Rafferty, S.D., and Grazio, J.L., 2006, Field manual for assessing internal and external anomalies in brown bullhead (Ameiurus nebulosus). Available at http://seagrant.psu.edu/publications/technical docs/bullheadfieldmanual.pdf.

R Core Team, 2012, R: A language and environment for statistical computing: Vienna, Austria, R Foundation for Statistical Computing, accessed at http://www.R-project.org/.

Robinson M.D., McCarthy D.J., and Smyth. G.K., 2010, edgeR: a Bioconductor package for differential expression analysis of digital gene expression data: Bioinformatics, v. 26, p.139-140.

Rodriguez-Cea, A., Ayllon, F., and Garcia-Vazquez, E., 2003, Micronucleus test in freshwater fish species: an evaluation of its sensitivity for application in field surveys: Ecotoxicology and Environmental Safety, v. 56, p. 442-448. 
Sanseverino, J., Gupta, R.K., Layton, A.C., Patterson, S.S., Ripp, S.A., Saidak, L., Simpson, M.L., Schultz, T.W., and Sayler, G.S., 2005, Use of Saccharomyces cerevisiae BLYES expressing bacterial bioluminescence for rapid, sensitive detection of estrogenic compounds: Applied Environmental Microbiology, v. 71, p. 4455-4460.

Schmitt, C.J., and Dethloff, G.M., eds., 2000, Biomonitoring of Environmental Status and Trends (BEST) Program: Selected methods for monitoring chemical contaminants and their effects in aquatic ecosystems: Federal Government Series, Information and Technology Report 2000-0005. 81 p.

Schmitt, C.J., ed., 2002. Biomonitoring of environmental status and trends (BEST) program:

Environmental contaminants and their effects on fish in the Mississippi River basin. Federal Government Series Biological Science Report 2002-0004, 241 p.

Sepúlveda, M.S., Johnson, W.E., Higman, J.C., Denslow, N.D., Schoeb, T.R., and Gross, T.S., 2002, An evaluation of biomarkers of reproductive function and potential contaminant effects in the Florida largemouth bass (Micropterus salmoides floridanus) sampled from the St. Johns River: Science of the Total Environment, v. 289, p. 133-144.

Sindhe, V.R., and Kulkarni, R.S., 2004, Gonadosomatic and hepatosomatic indices of the freshwater fish Notopterus notopterus (Pallas) in response to some heavy metal exposure: Journal of Environmental Biology, v. 25, p. 365-368.

Smith, I.R., 1990, Erythrocytic micronuclei in wild fish from Lakes Superior and Ontario that have pollution-associated neoplasia: Journal of Great Lakes Research, v. 16, p. 139-142.

Smith, I.R., Ferguson, H.W., and Hayes, M.A., 1989. Histopathology and prevalence of epidermal papillomas epidemic in brown bullhead, Ictalurus nebulosus (Lesueur) and white sucker, Catostomus commersoni (Lecepede), populations from Ontario, Canada: Journal of Fish Diseases, v. 12, p. 373-388.

Smith, S.B., Donahue, A., Lipkin, R., Blazer, V.S., Schmitt, C.J., and Goede, R.W., 2002, Illustrated field guide for assessing external and internal anomalies in fish: Federal Series: Information and Technology Report 2002-0007, 56 p.

Stavreva, D.A., P. Klausmeyer, A.A. George, L. Varticovski, D. Sack, T.C. Voss, R.L. Schiltz, V.S. Blazer, L.R. Iwanowicz, G.L. Hager, 2012, Prevalent glucocorticoid and androgen activity in US water sources. Nature Scientific Reports 2:937

Stentiford, G.D., Longshaw, M., Lyons, B.P., Jones, G., Green, M., and Feist, S.W., 2003, Histopathological biomarkers in estuarine fish species for the assessment of biological effects of contaminants: Marine Environment Research, v. 55, p. 137-159.

Sugg, D.W., Chesser, R.K., Brooks, J.A., and Grasman, B.T., 1995, The association of DNA damage to concentrations of mercury and radiocesium in largemouth bass: Environmental Toxicology and Chemistry, v. 14, p. 661-668.

Tyler, C.R., Lange, A., Raull, G.C., Katsu, Y. and Iguchi, T., 2007. The roach (Rutilis rutilis) on a sentinel for assessing endocrine disruption: Environmental Science, v. 14, p. 235-253.

Waggott, D., Chu, K., Yin, S., Wouters, B.G., Lin, F-F., and Boutros, P.C., 2012, NanoStringNorm: an extensible R package for the pre-processing of NanoString mRNA and miRNA data: Bioinformatics, v. 28, p. 1546-1548.

Wheeler, J.R., Gimeno, S., Crane, M., Lopez-Juez, E., and Morritt, D., 2005, Vitellogenin: A review of analytical methods to detect (anti) estrogenic activity in fish: Toxicology Mechanisms and Methods, v. 15, p. 293-306.

Williams, D.E., 2012, The rainbow trout cancer model: Response to environmental chemicals and studies on promotion and chemoprevention: Comparative Biochemistry and Physiology, Part C, v. 155 , p. $121-127$. 
Wolf, J.C., and Wolfe, M.J., 2005, A brief overview of nonneoplastic hepatic toxicity in fish: Toxicological Pathology, v. 33, p. 75-85.

Woodling, J.D., Lopez, E.M., Maldonado, T.A., Norris, D.O., and Vajda, A.M., 2006, Intersex and other reproductive disruption of fish in wastewater effluent dominated Colorado streams.

Comparative Biochemistry and Physiology, Part C, v. 144, p. 10-15. 
ISSN 2331-1258 (online)

http://dx.doi.org/10.3133/ofr20141027 